\title{
The use of an integrative approach to identify coelomocytes in three species of the genus Holothuria (Echinodermata)
}

\author{
Vinicius Queiroz ${ }^{1}$ (0) | Manuela Mauro ${ }^{2}$ | Vincenzo Arizza ${ }^{2}$ | Márcio R. Custódio ${ }^{1}$ | \\ Mirella Vazzana ${ }^{2}$
}

${ }^{1}$ Departamento de Fisiologia Geral, Instituto de Biociências, University of São Paulo, São Paulo, Brasil

${ }^{2}$ Dipartimento di Scienze e Tecnologie Biologiche, Chimiche e Farmaceutiche (STEBICEF), Università di Palermo, Palermo, Italia

\section{Correspondence}

Vinicius Queiroz, Departamento de Fisiologia Geral, Instituto de Biociências, Universidade de São Paulo, Sala 300, Rua do Matão,

Travessa 14, n 101, Cidade Universitária, São Paulo 05508-090, Brasil.

Email: vinicius_ufba@yahoo.com.br

Funding information

FAPESP, Grant/Award Numbers: 2015/21460-5, 2018/14497-8; Fondo

Finalizzato alla Ricerca di Ateneo

\begin{abstract}
Coelomocytes in the Holothuroidea are traditionally identified according to their morphology through light, fluorescence, or electron microscopy. Former studies have typically used only one method, with few works combining two or more approaches. Studies using cytocentrifugation to study these cells are scarcer. Thus, for the first time, an integrative approach was used to compare coelomocytes in Holothuroidea. This approach consisted of living and stained cells, scanning electron microscopy (for spherule cells), and accurate morphometric analyses. Specifically, we used specimens of Holothuria grisea, Holothuria arenicola, and Holothuria tubulosa to test whether cytocentrifugation could be valuable in comparative studies with coelomocytes, whether an integrative approach could help to understand spherule cell diversity, and whether closely related species, even those having distinct geographic distributions and ecological requirements, would have a similar population of coelomocytes. Our results showed seven distinct cell types in these species, including phagocytes, fusiform cells, morula cells, acidophilic spherulocytes, spherulocytes, progenitor cells, and crystal cells. Total and differential cell counts, along with morphometric parameters, were similar among species. Morphometric analyses of spherule cells revealed consistent differences among the diameter of their cytoplasmic spherules, as well as a set of different morphotypes in acidophilic spherulocytes and spherulocytes. Cytospin preparations proved to be quite useful because they provided constant morphological and morphometric data, allowing accurate identification of the cell types and comparisons among species. Moreover, this study highlighted (1) that the spherule diameter is a good parameter to separate spherule cells and (2) a putative maturation process to acidophilic spherulocytes and spherulocytes. Lastly, we showed that the cells of these species are very similar, regardless of their geographic distribution and ecology. Thus, our work contributes to a better understanding of the coelomocytes in Holothuria, a genus with a wide geographic distribution. The present study may be useful to establish these species as important model organisms, as well as bring insights into the functions of coelomocytes.
\end{abstract}

KEYWORDS

cytocentrifugation, maturation process, phagocytes, sea cucumber, spherule cells 


\section{1 | INTRODUCTION}

Marine animals, mainly invertebrates, are very important environmental bioindicators (Mauro, Pérez-Arjona, et al., 2020; Parisi et al., 2017; Vazzana, Mauro, et al., 2020) and sources of bioactive molecules (Inguglia et al., 2020; Luparello, Mauro, Arizza, \& Vazzana, 2020; Luparello, Mauro, Lazzara, \& Vazzana, 2020; Mauro, Lazzara, et al., 2020). Understanding their immune responses and defense mechanisms is essential to understanding the management of environmental and physiological stress (e.g., Pipe \& Coles, 1995) and the production and storage of bioactive molecules (e.g., Balaneva et al., 2016). In this context, echinoderms are considered key organisms to achieve these objectives (Chiaramonte et al., 2020; Lazzara et al., 2019; Mauro et al., 2021; Vazzana, Ceraulo, et al., 2020).

Holothuroidea is one of the five extant classes belonging to the phylum Echinodermata (Pawson, 2007). Holothurians (sea cucumbers) are elongated and soft-bodied echinoderms, in which the remarkable pentameric symmetry seen in other classes is generally not so evident. Holothurians rely on their coelomic fluid and circulating coelomocytes to perform many of their physiological functions. For example, hemocytes have been reported to perform gas exchange, while spherulocytes and phagocytes seem to be associated with nutrition and immune responses (Smith, 1981).

Eleven different types of coelomocytes have been described in Holothuroidea, including phagocytes, hemocytes, spherulocytes, crystal cells, fusiform cells, giant cells, progenitor cells, minute corpuscles, brown bodies, vibratile cells, and lymphocytes (Hetzel, 1963; Queiroz et al., 2021; Ramírez-Gómez et al., 2010). Of these cell types, minute corpuscles were considered to be fragments of other coelomocytes (Hetzel, 1963), and brown bodies are currently understood as cellular aggregates, rather than single cells, that originate during immune responses (Canicattì et al., 1989a; Caulier et al., 2020). Moreover, the status of some cell populations is yet under debate. For example, vibratile cells were considered to be foreign bodies or organisms that are captured along with coelomic fluid during cell collection (Hetzel, 1963), and lymphocytes could in fact be progenitor cells, as both show nearly identical morphologies (Elisenkina \& Magarlamov, 2002; Fontaine \& Lambert, 1977). Giant cells, although observed in two species (Prompoon et al., 2015; Ramírez-Gómez et al., 2010), are not considered a real cell type (Ho \& Rast, 2016). Thus, although some studies have proposed that holothurians have up to nine cell types in their coelomic fluid (e.g., Elisenkina \& Magarlamov, 2002; Ho \& Rast, 2016; Xing et al., 2008), it is clear that the diversity of coelomocytes is not yet fully understood.

In Holothuroidea, as in all echinoderms, the coelomocytes are traditionally identified based on morphology (Vazzana et al., 2015; Xing et al., 2008). Most studies have assessed coelomocyte morphology with light microscopy through observations of live cells in suspension (e.g., Hetzel, 1963; Li et al., 2018) or fixed immediately after collection and analyzed through transmission electron microscopy (e.g., Elisenkina \& Magarlamov, 2002). In some studies, two or more methods were used together (Canicattì et al., 1989b; Xing et al., 2008), which certainly improves the analysis. By contrast, data from other methods such as cytochemistry and scanning electron microscopy (SEM) have hardly ever been used to study coelomocyte morphology (Bello et al., 2015; D'Ancona \& Canicattì, 1990). The use of morphometry in studies of coelomocytes in Holothuroidea is even scarcer, though it has been proven informative in studies of hemocytes in other invertebrates, including Mollusca and Arthropoda (Salimi et al., 2009; Silva et al., 2002).

Morphometric studies of coelomocytes in Echinodermata, especially in Holothuroida, are scarce, possibly because studies traditionally have looked at live cells spread on microscope slides (e.g., Pinsino et al., 2007). Coelomocytes in echinoderms actively change their shape (e.g., phagocytes and spherulocytes; Canicattì et al., 1989b; Matranga et al., 2005), and their morphology may be affected by abiotic parameters, such as temperature (Branco et al., 2013). In this context, morphological and morphometric parameters may be profoundly affected, which can compromise cell identification and measurements. As such, studies that integrate several methods to analyze coelomocytes, including cytochemistry and cytospin preparations, may provide further information about coelomocyte characteristics and diversity. In this sense, a recent study (Queiroz et al., 2021) showed that cytospin preparations are an additional tool to overcome the issue of mutable cell morphology and seem to allow comparative studies.

In the present study, we tested three hypotheses: First, that cytocentrifugation, used in an integrative approach, is a valuable tool in comparative studies of holothurian coelomocytes; second, that this integrative approach is useful to understand the diversity of spherule cells; and third, that phylogenetically related species, regardless of their distinct ecological niches or geographical distributions, have similar coelomocytes. We investigated three species belonging to the genus Holothuria: Holothuria grisea SelenKA 1867, Holothuria arenicola SEMPER 1868, and Holothuria tubulosa GMELIN 1791. We chose these species based on three main criteria. First, we considered their wide geographic distribution. H. grisea ranges from the United States (Florida) to southern Brazil and West Africa, and $\mathrm{H}$. tubulosa is found in the entire Mediterranean Sea, and some regions in the northern Atlantic Ocean (Hendler et al., 1995; Kazanidis et al., 2010). By contrast, $H$. arenicola is a circumtropical species, occurring in the Atlantic, Pacific, and Indian oceans (Purcell et al., 2012). Second, these species have different ecological requirements. Although all of them live associated with seagrass flats and sandy bottoms, $H$. grisea and $H$. tubulosa are epibenthic and closely associated with hard substrata, whereas $H$. arenicola is essentially infaunal, living completely buried in the sand (Hendler et al., 1995; Massin \& Jangoux, 1976). Third, they belong to the genus Holothuria, one of the most diverse (150 spp.; Borrero-Pérez et al., 2010), well-studied, and economically relevant groups in Holothuroidea (e.g., Kamyab et al., 2019; Purcell et al., 2012). Thus, our study contributes to a better understanding of coelomocyte diversity in Holothuroidea and how this cell diversity is affected in different but phylogenetically related species. 


\section{2 | METHODS}

\subsection{Animal collection, maintenance, and coelomic fluid collection}

Holothuria grisea and H. arenicola (Figure $1 \mathrm{~A}, \mathrm{~B}$ ) were collected in Brazil at the beginning of the summer (January) on the southeast $\left(23^{\circ} 49^{\prime} \mathrm{S}\right.$, $\left.45^{\circ} 25^{\prime} \mathrm{W}\right)$ and northeast $\left(13^{\circ} 00^{\prime} \mathrm{S}, 38^{\circ} 27^{\prime} \mathrm{W}\right)$ coasts, respectively. H. tubulosa (Figure 1C) was collected in Italy, also at the beginning of the summer (July) on the coast of Santa Flavia, Palermo $\left(38^{\circ} 05^{\prime} \mathrm{N}\right.$, $\left.13^{\circ} 32^{\prime} \mathrm{E}\right)$. We analyzed the coelomocytes of 18 individuals, six of each species, which ranged $8-12 \mathrm{~cm}$ in relaxed body length. All species were acclimated for 1 week before the analyses under conditions similar to those found in nature during collections. Individuals of all species were maintained in three different $80-\mathrm{L}$ aquariums (temperature, $24 \pm 2{ }^{\circ} \mathrm{C}$; salinity, $35 \pm 2 \mathrm{psu}$; photoperiod, $12: 12 \mathrm{~h}$ ) with constant aeration, and were fed daily with commercial invertebrate pellets (Azoo, Taikong Corp. Taiwan).

Immediately before coelomic fluid collection, each individual was removed from the tank, allowed to initially contract and expel water (due to handling), rinsed with water from the aquarium, and dried with a paper tissue to avoid contamination of the coelomic fluid. The coelomic fluid was collected individually through an incision on the anterodorsal region (Vazzana et al., 2015), and the fluid (1 ml) was transferred into a vial containing $1 \mathrm{ml}$ of ice-cold isosmotic anticoagulant solution (ISO-EDTA: $0.5-\mathrm{M} \mathrm{NaCl}, 20-\mathrm{mM}$ Tris- $\mathrm{HCl}, 30-\mathrm{mM}$ EDTA; $\mathrm{pH}$ 7.4). We used a Neubauer chamber to obtain total cell counts (TCCS) at the initial dilution, and we adjusted the cell density of this initial suspension to $10^{6} \mathrm{cell} / \mathrm{s} / \mathrm{ml}$ with the anticoagulant solution to obtain differential cell counts (DCCs), recorded as the percentage of each cell type.

\subsection{Identification and morphological characterization of coelomocytes in Holothuria}

The different cell types in the coelomic fluid were characterized using an integrated approach consisting of live cells in suspension, cytological preparations, and SEM. Cells were identified according to specific literature for Holothuroidea (e.g., Hetzel, 1963; Vazzana et al., 2015;
Xing et al., 2008). The nomenclature of the different types of spherule cells observed here followed Vazzana et al. (2015). The term spherule cells will be used hereafter to refer collectively to the three spherulefilled cell types-morula cell, acidophilic spherulocyte, and spherulocyte-found in the species studied here. Spherules are vacuole-like structures filled with small granules.

Live cells were observed just after collection, by placing drops of newly collected coelomic fluid suspension containing $1 \times 10^{6}$ cells $/ \mathrm{ml}$ on microscope slides and covering them with a coverslip. Because some types suffered a drastic change in their nuclear and cytoplasmic shape or size, the coelomocytes were analyzed just after slide preparations (TO) and after a 20-min timespan (T1). Cell measurements were made only with T1 cells, in which the morphological changes seemed to have stabilized.

For cytological analysis, cells were prepared as described in Queiroz et al. (2021). Briefly, cells were placed on microscope slides using a cytocentrifuge (FANEN 248 simultaneous fluid removal cytocentrifuge, $80 \mu \mathrm{l}$ per spot, $80 \times \mathrm{g}$ for $5 \mathrm{~min}$ ), fixed for $45 \mathrm{~min}$ in formaldehyde sublimate, and stained with toluidine blue (TB) or Mallory's trichrome (MT) following standard methods (Queiroz et al., 2021; Queiroz \& Custódio, 2015). MT was chosen as the main stain for crystal cells and spherule cells because it allows for unambiguous identification of these subpopulations (mainly spherule cells). On the other hand, TB is quite useful to stain phagocytes, filiform cells, and progenitor cells.

Spherule cells were further analyzed using SEM. To this end, cells were placed on 10-mm round coverslips using cytocentrifugation and fixed in formaldehyde sublimate as previously described.. Subsequently, the coverslips were dipped for $40 \mathrm{~min}$ in MilliQ water to remove salts, air-dried at room temperature, and processed for SEM analyses as usual (Queiroz et al., 2021). The morphology of cells from specimens of $H$. grisea was characterized at both T0 and T1. Because the morphological changes between T0 and T1 were similar in all species, only cells in T1 are described for $\mathrm{H}$. arenicola and $\mathrm{H}$. tubulosa.

\section{3 | Coelomocyte morphometry}

Diameters of the cytoplasm and nucleus were measured in representative coelomocytes of different types. In the three types of spherule
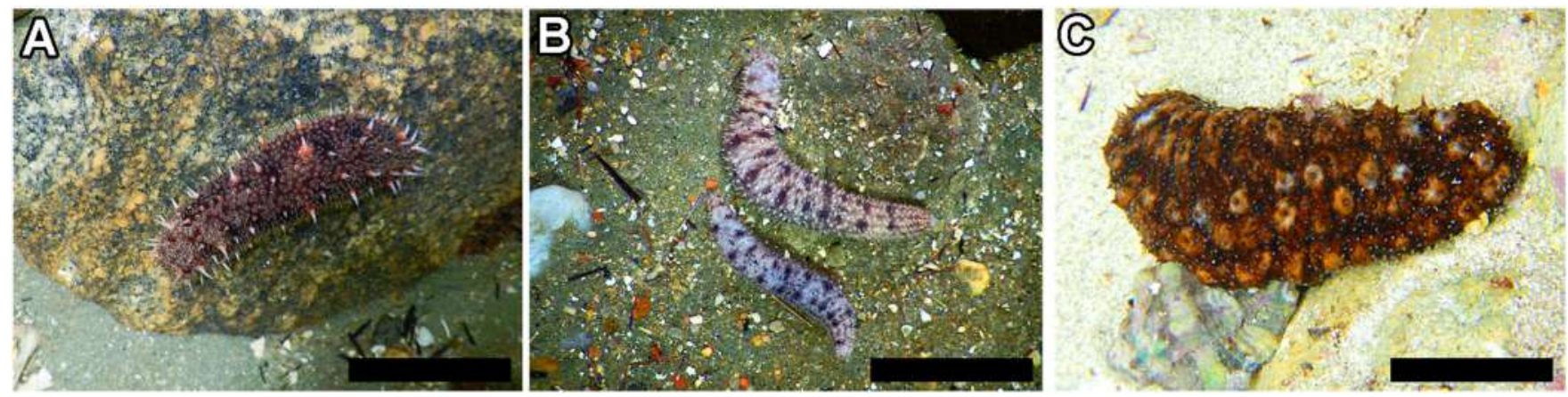

FIG URE 1 Species of Holothuria studied. A. Holothuria grisea. B. Holothuria arenicola. C. Holothuria tubulosa. Scale $=10 \mathrm{~cm}$ 
cells, the diameter of cytoplasmic spherules was also measured, and the nucleus:cytoplasm ratio (NCR) was calculated. When the cytoplasm, nucleus, or spherules were not circular in outline, the Ferret diameter was considered as the diameter. In living and stained preparations, 25 cells of each type were measured. In the spherule cells, the diameter of 30 spherules was measured (three spherules in each cell).

In acidophilic spherulocytes and spherulocytes, which presented four different morphotypes (M1-M4), morphological and morphometric parameters of each morphotype were described separately. Considering that the morphotypes were not so common in the coelomic fluid, morphometric analyses were based only on the observation of 10 cells of each morphotype ( $n=40$ per spherule cell). Nucleus and cytoplasm diameter, along with the NCR and the diameter of the spherules, were measured as described previously.

In crystal cells, the length of the intracytoplasmic crystal was measured. Because of the small number of crystal cells in stained preparations, only 10 cells were measured.

\subsection{Statistical analyses}

Measurements were obtained from digital images and performed with ImageJ software (NIH). Results from TCC, DCC, nucleus, cytoplasm, and spherule diameters of live and stained coelomocytes are presented as means \pm standard deviation, followed by the range of values. We used one-way analysis of variance (ANOVA) to analyze the differences in the TCC and DCC among species. Spherule diameters of live and stained spherule cells were compared using two-way ANOVA, with species and cell type as factors, to analyze both live and stained cells. A two-way ANOVA was also used to analyze the nucleus diameter, cytoplasm diameter, NCR, and spherule diameter of the different morphotypes of stained acidophilic spherulocytes and spherulocytes, with species and morphotype as factors. Tukey multiple comparison post hoc tests were applied to one-way and two-way ANOVA when necessary to identify the source of significance. Differences in one-way and two-way ANOVA were considered significant if $p<.05$. All statistical analyses were performed in the Graphpad Prism 7 software.

\section{\begin{tabular}{l|l}
3 & RESULTS
\end{tabular}}

All species showed similar values of total and DCCs (Table 1). In general, phagocytes and progenitor cells were the most frequent type of coelomocyte (Table 1). Our study revealed that seven distinct cell populations occur in the coelomic fluid of the study species, including phagocytes (petaloid and filopodial forms); fusiform cells; three types of spherule cells, termed morula cells, acidophilic spherulocytes, and spheruloctyes; progenitor cells; and crystal cells. Although giant cells were observed in stained preparations, they did not seem to be a real cell type because they were not found in live preparations; rather, they were ruptured morula cells. No hemocytes were observed in the species analyzed here. In general, coelomocytes were quite similar in morphology, regardless of species (Figures 2 and 3), but some differences were observed in the morphometric parameters (Tables 2 and 3). The descriptions that follow are based on specimens of $H$. grisea at TO and general descriptions common to all species at $\mathrm{T} 1$.

\section{1 | Morphological and morphometric characterization of coelomocytes from Holothuria species}

\subsection{1 | Phagocytes}

Live cells at TO had a large cell body with a prominent nucleus (Table 2) and remarkable thread-like pseudopodia or roundish bladder-like expansions in filiform and petaloid phagocytes, respectively (Figure 2AO,BO). At T1, the pseudopodia of filiform phagocytes decreased in length at the same time that the number of projections increased (Figures $2 A 1$ and $3 A 1, I 1)$. In the petaloid form, the size and number of bladder-like expansions also decreased (Figures 2B1 and 3B1,J1) along with the appearance of blunt pseudopodia. Neither of the morphotypes of phagocytes showed specific reactions when stained with TB or $M T$, and were, in general, morphologically (Figures 2A,B and 3A,B,I,J) and morphometrically (Tables 2 and 3) similar to live cells.

TAB LE 1 Total and differential cell counts of coelomocytes from individuals of three species in the genus Holothuria

\begin{tabular}{|c|c|c|c|c|c|c|c|c|}
\hline \multirow[b]{2}{*}{ Species } & \multirow{2}{*}{$\begin{array}{l}\text { Total cell } \\
\text { count }\left(\times 10^{6}\right. \\
\text { cells } / \mathrm{ml})\end{array}$} & \multicolumn{7}{|c|}{ Differential cell count (\%) } \\
\hline & & Phagocytes & $\begin{array}{l}\text { Fusiform } \\
\text { cells }\end{array}$ & $\begin{array}{l}\text { Morula } \\
\text { cells }\end{array}$ & $\begin{array}{l}\text { Acidophilic } \\
\text { spherulocytes }\end{array}$ & Spherulocytes & $\begin{array}{l}\text { Progenitor } \\
\text { cells }\end{array}$ & $\begin{array}{l}\text { Crystal } \\
\text { cells }\end{array}$ \\
\hline $\begin{array}{l}\text { Holothuria } \\
\text { grisea }\end{array}$ & $8.37 \pm 0.61$ & $40.19 \pm 8.87$ & $7.22 \pm 1.02^{*}$ & $2.55 \pm 2.54$ & $6.56 \pm 5.44$ & $4.54 \pm 8.45^{*}$ & $34.31 \pm 3.78^{*}$ & $4.64 \pm 1.59$ \\
\hline $\begin{array}{c}\text { Holothuhria } \\
\text { arenicola }\end{array}$ & $8.57 \pm 0.76$ & $39.33 \pm 5.84$ & $4.14 \pm 1.49$ & $4.68 \pm 1.83$ & $7.77 \pm 2.14$ & $17.93 \pm 5.74$ & $25.00 \pm 8.15^{*}$ & $1.16 \pm 0.86^{*}$ \\
\hline $\begin{array}{l}\text { Holothuria } \\
\text { tubulosa }\end{array}$ & $8.80 \pm 2.19$ & $51.48 \pm 10.39^{*}$ & $3.30 \pm 1.19$ & $4.55 \pm 2.90$ & $9.97 \pm 5.83$ & $15.07 \pm 8.62$ & $12.62 \pm 3.64^{*}$ & $3.02 \pm 1.95$ \\
\hline
\end{tabular}

Note: Values are presented as means $\pm S D$.

*indicates significant differences among species $(p<.05)$ in one-way ANOVA. 
To

Ao
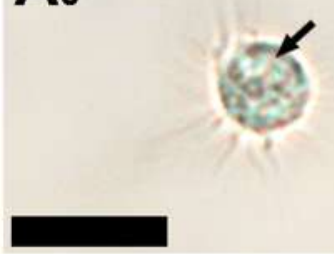

Bo

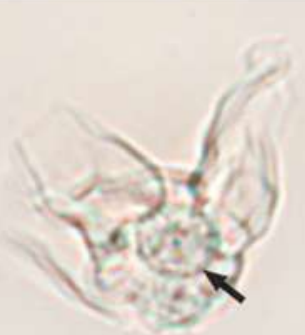

$\mathrm{C}_{0}$

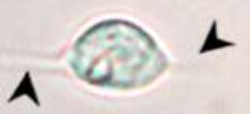

Do

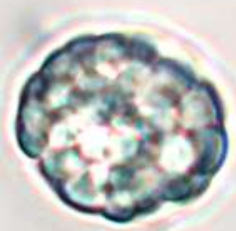

Eo

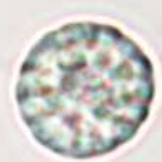

$F_{0}$

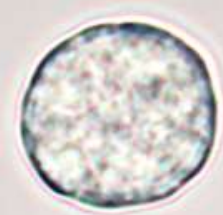

$\mathbf{G}_{0}$

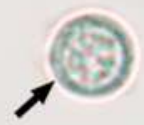

$\mathrm{H}_{0}$

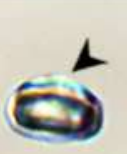

$\mathrm{T}_{1}$

$\mathrm{A}_{1}$

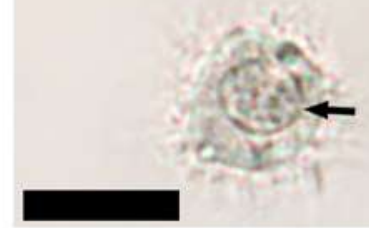

$\mathrm{B}_{1}$

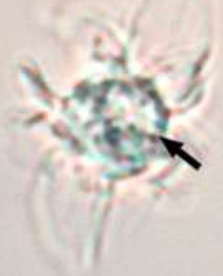

$\mathbf{C}_{1}$

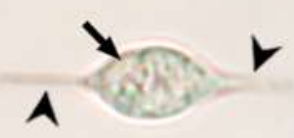

$\mathrm{D}_{1}$

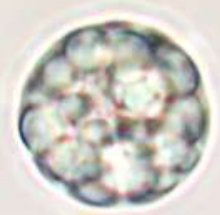

$E_{1}$

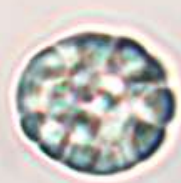

$F_{1}$

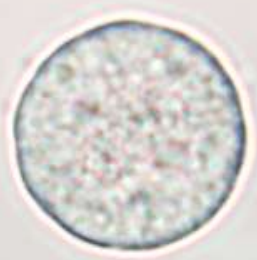

$\mathbf{G}_{1}$

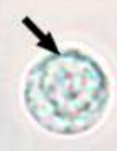

$\mathrm{H}_{1}$
Stained

A

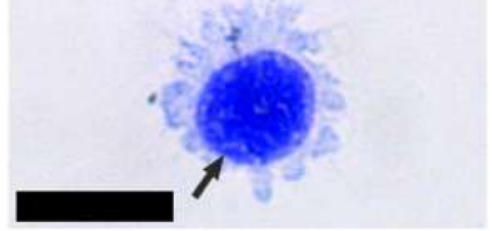

B

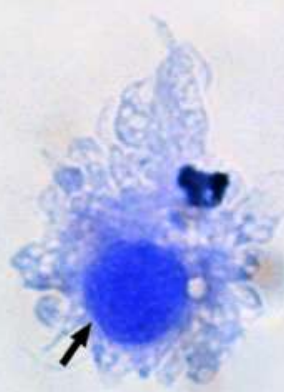

C

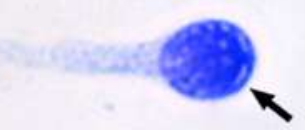

D

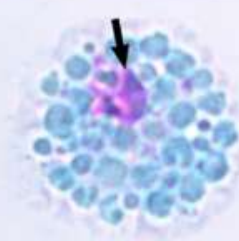

E

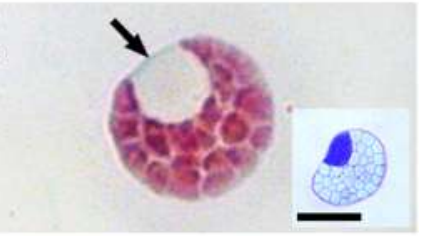

F

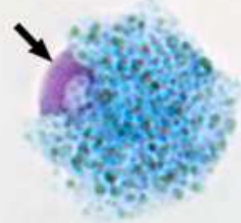

G

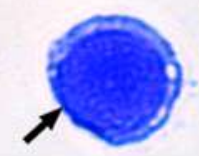

H

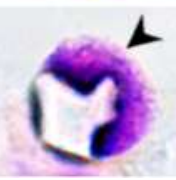




\subsection{2 | Fusiform cells}

Fusiform cells were small coelomocytes (Tables 2 and 3) with a spindle-like shape, bearing one cytoplasmic projection on each end. At TO, live cells usually had a thin and delicate outline with subtle cytoplasmic projections stemming from the cell body (Figure 2C0). However, after they were prepared on microscope slides (T1), fusiform cells acquired a more granulous and rough cytoplasm, with more pronounced cytoplasmic expansions (Figures $2 \mathrm{C} 1$ and $3 \mathrm{C} 1, \mathrm{~K} 1$ ). In cytological preparations, fusiform cells had a larger nucleus (Table 3) and an elongated cytoplasm, without specific reactions when stained with TB or MT (Figures $2 \mathrm{C}$ and $3 \mathrm{C}, \mathrm{K}$ ).

\subsection{3 | Spherule cells}

Morphological analyses consistently showed three distinct subtypes of spherule cells-morula cells, acidophilic spherulocytes, and spheruloctyes-in the species studied herein. These could be accurately identified by their general aspect, mainly by the shape of the cytoplasmic spherules when alive and the cytochemical affinities when stained. Morphometry revealed that, although the cytoplasm and nucleus diameter show variations among species (Tables 2 and 3), the diameter of the cytoplasmic spherules remained constant and allowed undoubted recognition (Table 4). The spherule diameter in live spherule cells was not significantly different among species ( $F[2$, $261]=1.771 ; p=.1723$ ), but was significantly different among cell types $(F[2,261]=1,139 ; p<.0001)$, with a significant interaction between these two factors $(F[4,261]=2.991 ; p=.0194)$. Similarly, the spherule diameter in stained cells was not significantly different among species $(F[2,261]=0.8782 ; p=.4168)$, but was significantly different among cell types $(F[2,261]=1,073 ; p<.0001)$, with a significant interaction between these two factors $(F[4,261]=4.101$; $p<.0031)$. Specific details are provided in Table S1.

\section{Morula cells}

Morula cells were large and (Tables 2 and 3 ) filled with large spherules (Figure 4, Table 4) of irregular shape (Figures 2 and 3), which always had a smooth appearance. At T0, these cells showed larger spherules with a more regular shape (Figure 2D0), but after preparation on the slides (T1), they became visibly irregular in shape (Figures 2D1 and 3D1,L1). In cytospin preparations, the cells were quite evident because of their large areas of cytoplasm (Table 3) filled with irregular, large spherules that stained light blue in MT or purple in TB preparations ( $\beta$ metachromasy; Sridharan \& Shankar, 2012), indicating the presence of mucopolysaccharides (Figures 2D, D inset and 3D,L).

\section{Acidophilic spherulocytes}

Acidophilic spheruloctyes were small coelomocytes (Tables 2 and 3) crowded with regular, medium-sized spherules (Figure 4, Table 4). At TO, the spherules generally were a spherical shape (Figure 2E0), which became a little bit squarish after some time (T1) on the microscope slide (Figures 2E1 and 3E1,M1). The nucleus of live cells was usually difficult to see, but in some cases, it was quite evident (Figure 3M1). In cytochemical preparations, the spherules showed a remarkable pinkish color when stained with $\mathrm{MT}$, indicating its protein moiety (Figures 2E and $3 \mathrm{E}, \mathrm{M}$ ), and a grayish blue color in TB stain (Figure 2E inset).

\section{Spherulocytes}

Spherulocytes were large cells (Tables 2 and 3) bearing no visible spherules but with very small cytoplasmic inclusions (i.e., granules; Figure 4, Table 4), which give a finely granular appearance to this spherule cell. At TO, granules were so small that cell appearance was smooth rather than granular (Figure 2FO), but this aspect changed considerably at T1 (Figures 2F1 and 3F1,N1). In stained preparations, the cells were larger (Table 3 ), and the small granules were quite evident (Figures $2 \mathrm{~F}$ and $3 \mathrm{~F}, \mathrm{~N}$ ). The spherulocyte stained light blue in MT and blue in TB (Figure 3F, $F$ inset).

\subsection{4 | Progenitor cells}

Progenitor cells were small round coelomocytes (Tables 2 and 3) with a thin cytoplasmic layer surrounding a huge nucleus. This cell was quite round when in suspension (TO), with no visible cytoplasm (Figure 2G0). However, after the cell spreads on the microscope slide (T1), a thin layer of cytoplasm with few vacuoles could be observed surrounding its central nucleus (Figures $2 \mathrm{G1}$ and 3G1,O1). In cytospin preparations, progenitor cells showed the same pattern as observed in live preparations, with no specific reactions when stained with TB or MT (Figures 2G and 3G,O).

\subsection{5 | Crystal cells}

Crystal cells were small coelomocytes (Tables 2 and 3) bearing an elongated, squarish, or diamond-shaped cytoplasmic crystal. At T0, the cell was the shape of the intracoelomic crystal, with a very thin layer of cytoplasm surrounding it (Figure 2HO), but the cytoplasm became more visible in $\mathrm{T} 1$ (Figures $2 \mathrm{H} 1$ and $3 \mathrm{H} 1, \mathrm{P} 1$ ). In cytochemical preparations, the crystal was usually not detectable, leaving instead a transparent spot with a similar shape (Figures $2 \mathrm{H}$ and $3 \mathrm{H}, \mathrm{P}$ ).

FIGURE 2 Live and stained coelomocytes of Holothuria grisea. Live cells were analyzed immediately after collection ( $\left.T_{0}\right)$, and after 20 min on microscope slides ( $\left.T_{1}\right)$. A0, A1, A. Filiform phagocytes. B0, B1, B. Petaloid phagocytes. C0, C1, C. Fusiform cell. D0, D1, D. Morula cell. E0, E1, E. Acidophilic spherulocyte. F0, F1, F. Spherulocyte. G0, G1, G. Progenitor cell. HO, H1, H. Crystal cell. Cells were stained with toluidine blue (A-C, G, and insets) and Mallory's trichrome (D-F, H). Arrows indicate nucleus; arrowheads indicate cytoplasmic projections. Scales: $A 0=$ for T0 cells $(10 \mu \mathrm{m}) ; \mathbf{A} 1=$ for T1 cells $(10 \mu \mathrm{m}) ; \mathbf{A}=$ for stained cells $(10 \mu \mathrm{m})$ 


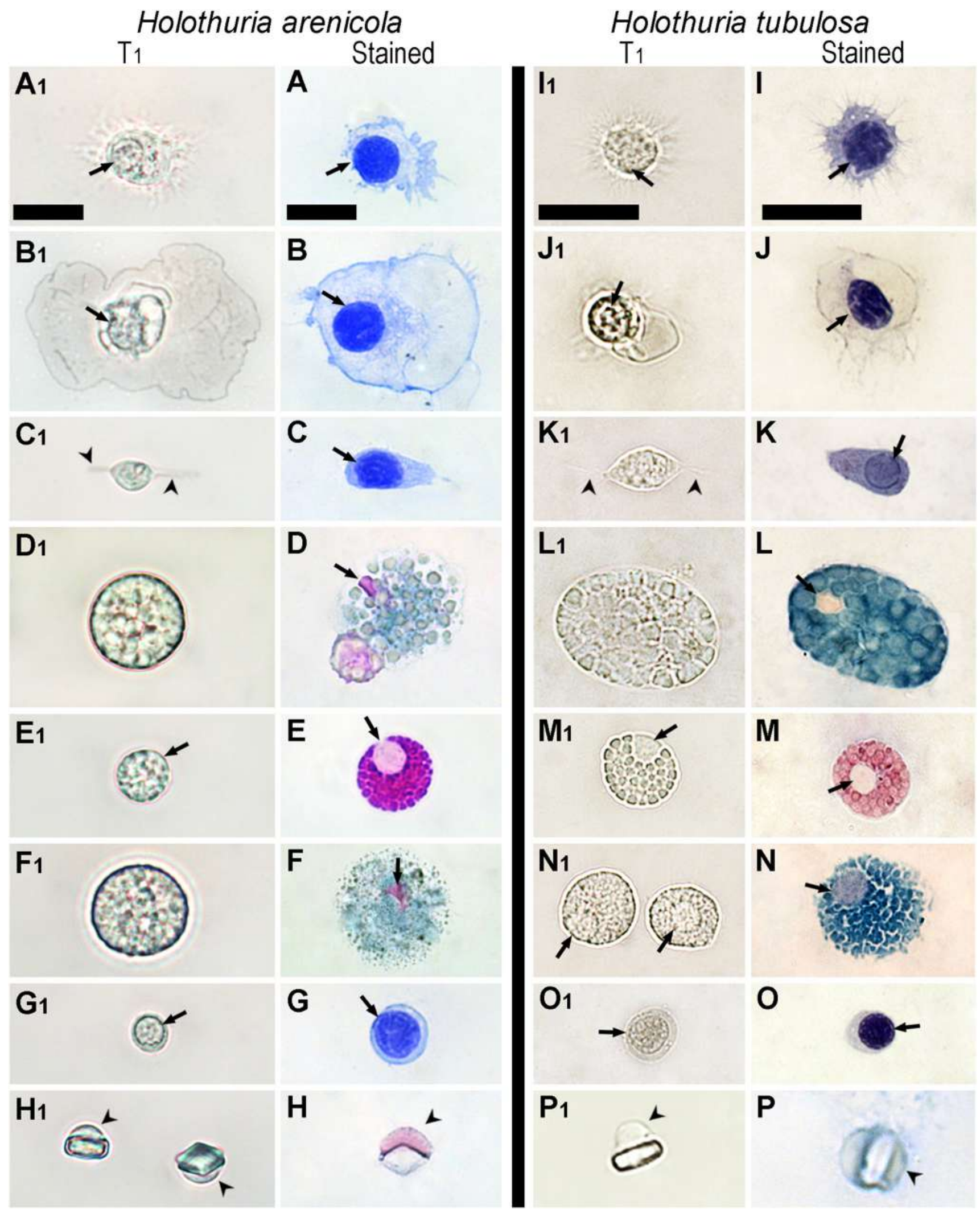

FIGURE 3 Live and stained coelomocytes of Holothuria arenicola and H. tubulosa. Live cells were analyzed 20 min after collection (T1) and after staining. A1, A. I1, I. Filiform phagocytes. B1, B. J1, J. Petaloid phagocytes. C1, C. K1, K. Fusiform cell. D1, D. L1, L. Morula cell. E1, E. M1, M. Acidophilic spherulocyte. F1, F. N1, N. Spherulocyte. G1, G. O1, O. Progenitor cell. H1, H. P1, P. Crystal cell. Cells were stained with toluidine blue (A-C, G, I-K, O) and Mallory's trichrome (D-F, H, L-N, P). Arrows indicate nucleus; arrowheads indicate cytoplasmic projections. Scales: $\mathbf{A} \mathbf{1}=$ for live cells of $H$. arenicola $(10 \mu \mathrm{m}) ; \mathbf{A}=$ for stained cells of $H$. arenicola $(10 \mu \mathrm{m}) ; \mathbf{I} \mathbf{1}=$ for live cells of $H$. tubulosa $(10 \mu \mathrm{m}) ; \mathbf{I}=$ for stained cells of $H$. tubulosa $(10 \mu \mathrm{m})$ 
TAB LE 2 Diameters, in micrometers, of the nucleus and cytoplasm in live cells of different species in the genus Holothuria

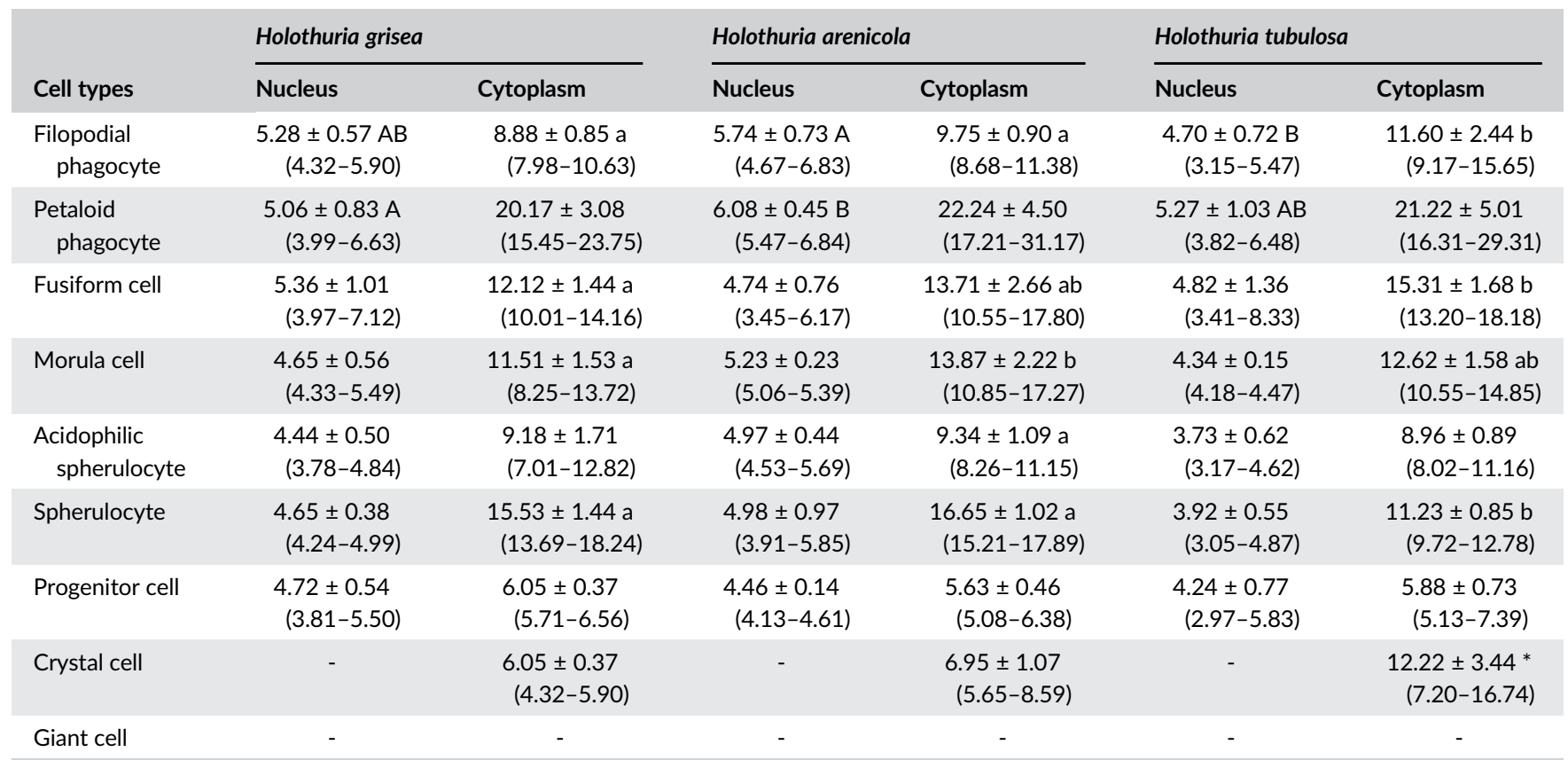

Note: Values are presented as means $\pm S D$ (followed by range). Capital letters indicate significant differences between the nucleus diameters of different species; lowercase letters indicate differences between cytoplasm diameters of different species; asterisk indicates differences among crystals of different species; superscripted numbers indicate the number of measured structures; hyphen indicates that the structure or cell was not found. Differences were considered statistically significant in one-way ANOVA if $p<.05$.

TAB LE 3 Diameters, in micrometers, of the nucleus and cytoplasm in stained cells $(n=25)$ from different species in the genus Holothuria

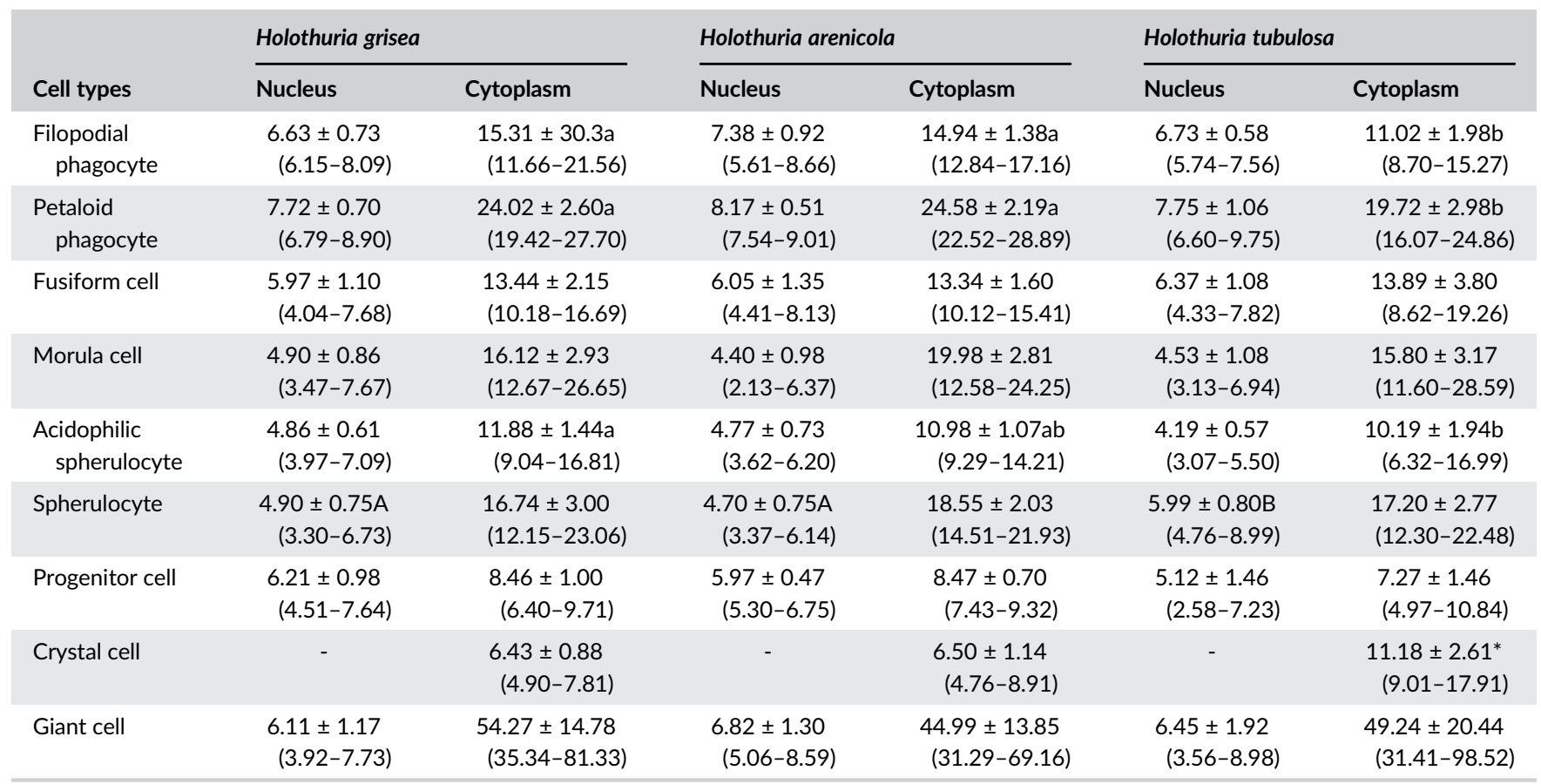

Note: Values are presented as means $\pm S D$ (followed by range). Capital letters indicate significant differences in nucleus diameter between different species; lowercase letters indicate significant differences in cytoplasm diameter between different species. In crystal cells, significant difference in crystal size is indicated by an asterisk; hyphen indicates that the structure was not found. Differences were considered statistically significant in one-way ANOVA if $p<.05$. 
TAB LE 4 Diameter of spherules or granules in live and stained spherule cells (30 cells for each treatment) from three species of the genus Holothuria

\begin{tabular}{|c|c|c|c|}
\hline Spherule cells & Holothuria grisea & Holothuria arenicola & Holothuria tubulosa \\
\hline \multicolumn{4}{|l|}{ Live cells } \\
\hline Morula cell & $3.14 \pm 0.64(4.76-2.34)$ & $3.27 \pm 0.64(4.97-2.06)$ & $3.42 \pm 0.47(4.14-2.78)$ \\
\hline Spherulocyte & $0.81 \pm 0.13(0.99-0.54)$ & $0.75 \pm 0.16(0.98-0.42)$ & $0.66 \pm 0.10(0.85-0.48)$ \\
\hline \multicolumn{4}{|l|}{ Stained cells } \\
\hline Acidophilic spherulocyte & $1.21 \pm 0.28(1.81-0.83)$ & $1.35 \pm 0.13(1.53-1.17)$ & $1.29 \pm 0.15(1.59-1.10)$ \\
\hline Spherulocyte & $0.71 \pm 0.13(0.97-0.56)$ & $0.84 \pm 0.12(0.99-0.67)$ & $0.66-0.12(0.90-0.47)$ \\
\hline
\end{tabular}

Note: Values are means $\pm S D$ (followed by range). All diameters were significantly different between cell types within a species; no diameters were significantly different between species within a cell type. Differences were considered statistically significant in two-way ANOVA if $p<.05$.
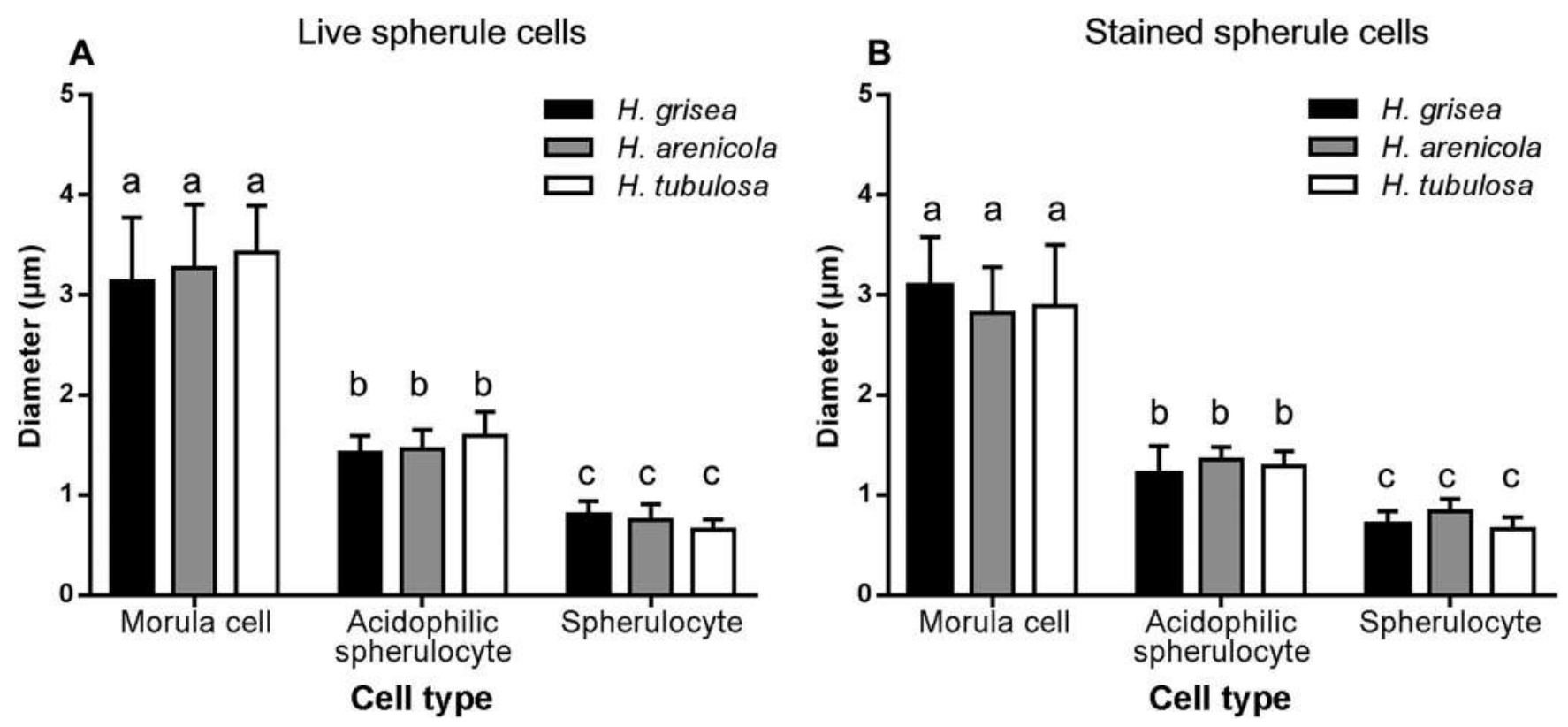

FIGURE 4 Diameter of spherules in three types of spherule cells of Holothuria grisea, H. arenicola, and H. tubulosa. A. Living spherule cells. B. Stained spherule cells. Different letters indicate significant differences $(p<.05)$ among cell types in two-way ANOVA analyses. Error bars represent the standard deviation of the mean. ANOVA, analysis of variance; ASp, acidophilic spherulocytes; MC, morula cells; Sp, spherulocytes

\section{H. grisea}

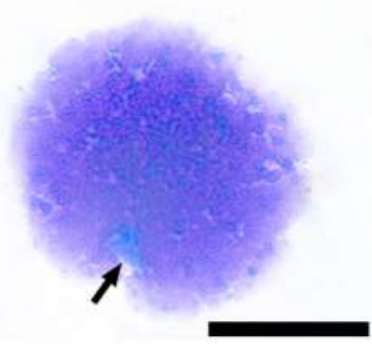

H. arenicola

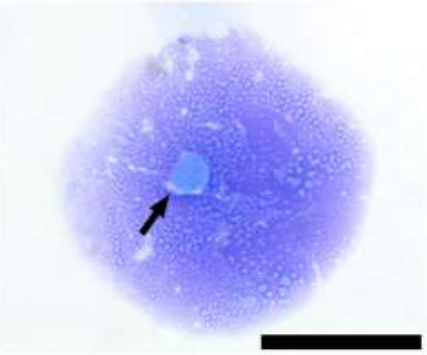

H. tubulosa

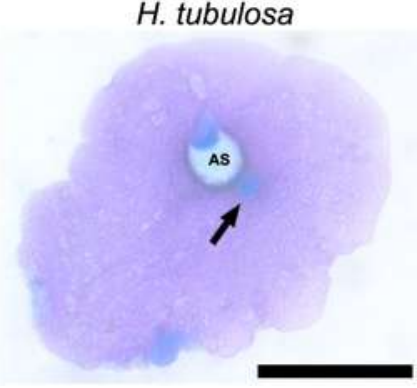

FIG URE 5 Giant cells (possibly damaged morula cells) of three species of Holothuria, stained with toluidine blue. Note the purplish spread cytoplasm ( $\beta$-metachromasy) and the nucleus in blue. AS, acidophilic spherulocyte; black arrows indicate nucleus. Scale $=20 \mu \mathrm{m}$ 


\subsection{6 | Giant cells}

Cells bearing the features of giant cells were not observed in live preparations. By contrast, in stained slides, they were relatively common and very similar to the cell type described in Ramírez-Gómez et al. (2010). These cells showed a very large and spread cytoplasm (Table 3), which stained purple in TB slides (Figure 5A-C), similar to the staining observed for morula cells (Figure 2D inset). Considering their morphology and stain properties, giant cells resembled ruptured morula cells in which the leaked cytoplasm spilled on the slide, rather than a separate cell type.

\section{2 | Morphological aspects of the spherule cells under SEM}

A detailed morphological characterization of spherule cells was performed through SEM. Using this method, we confirmed the aspects described in the live and stained preparations. In all species, morula cells and acidophilic spherulocytes were thicker cells in which the nucleus was lower (thinner) if compared with the surrounding cytoplasm (Figure 6A-F). By contrast, spherulocytes were considerably less thick and usually quite adhered to the coverslip (Figure $6 \mathrm{H}-\mathrm{I}$ ); the nucleus of spherulocytes was, in general, similar in height (thickness)
H. grisea
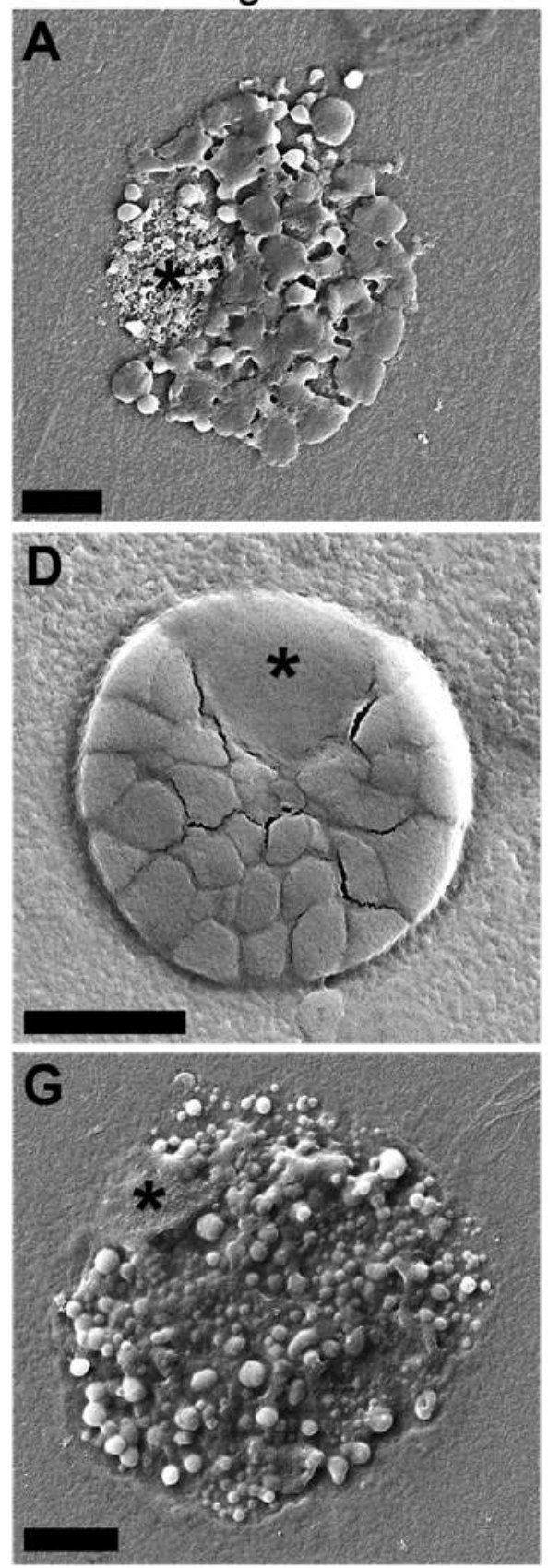

H. arenicola
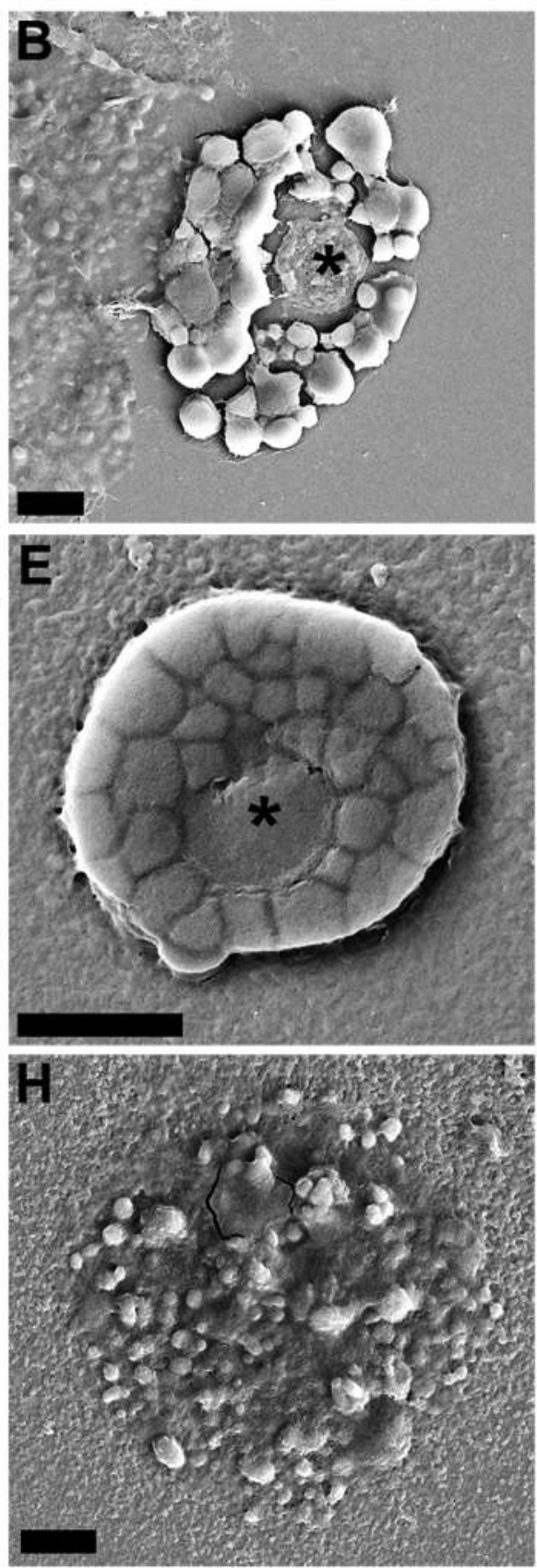

H. tubulosa
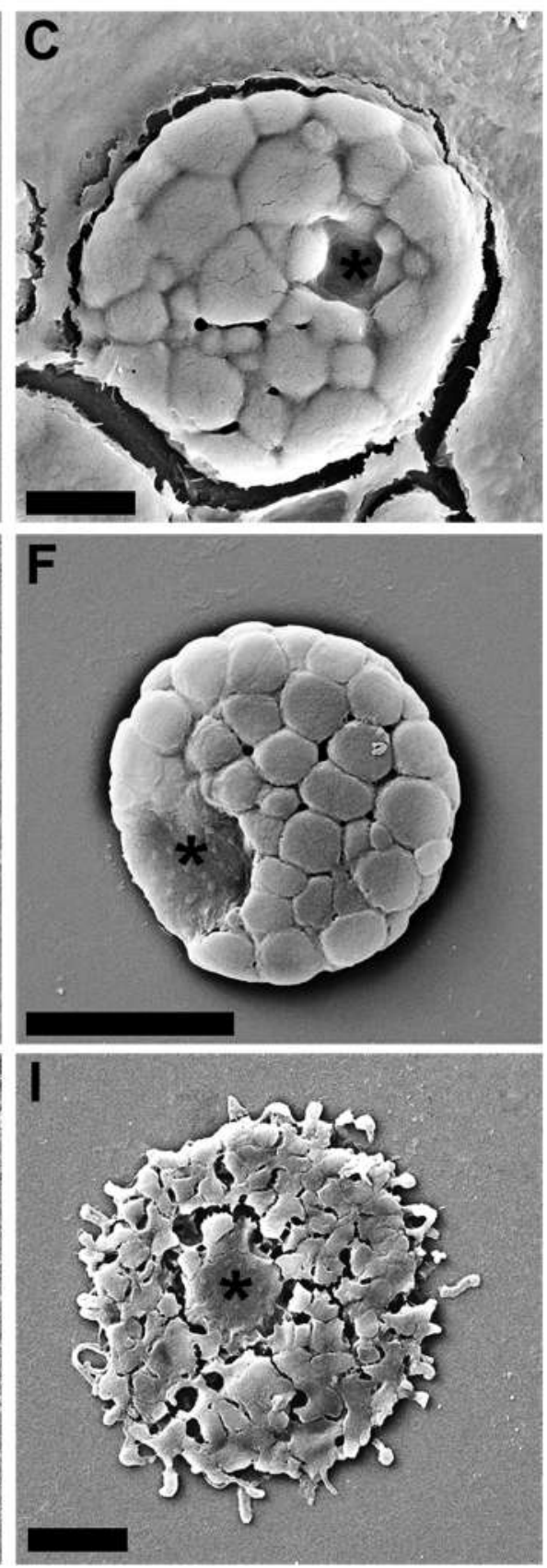

FIGURE 6 Morphological details of three types of spherule cells of Holothuria grisea, $H$. arenicola, and $H$. tubulosa in scanning electron microscopy (SEM) preparations. A-C. Morula cell. D-F. Acidophilic spherulocyte. G-I. Spherulocyte. Asterisks indicate nucleus. Scale $=4 \mu \mathrm{m}$ 
to the surrounding cytoplasm, although in some cases, it may be lower (thinner) than the surrounding cytoplasm.

The morula cells had cytoplasmic spherules with irregular profiles, ranging from quite spherical to ellipsoidal or elongated (Figure 6A-C). Their size also ranged from small $(\sim 0.5 \mu \mathrm{m})$ to very large $(>3.5 \mu \mathrm{m})$ in the same cell (Figure 6C). The cytoplasm of morula cells in SEM was similar to that observed in stained preparations, ranging from cells in which the spherules were clumped together (Figure $6 \mathrm{C}$ ) to those in which they were more or less separated (Figure 6A,B). The acidophilic spherulocytes had spherules with more regular profiles, ranging from quite spherical to somewhat square (Figure 6E,F), although some elongated spherules were seen (Figure 6D). The cytoplasm of acidophilic spherulocytes was typically rounded, with the spherules quite close to each other, and the nucleus was peripheral to subcentral. The spheruloctyes were the most distinct type of spherule cell because of their small spherules, which give the cells a finely granular appearance (Figure 6G-I). The small cytoplasmic spherules were quite similar in shape and size and were usually very close to each other. This organization sometimes impaired the visualization of individualized granules, and a homogeneous cytoplasmic mass was visible instead (Figure 6H,I).

\section{3 | Morphological variation in the spherule cells}

An analysis of stained preparations revealed a continuum of morphotypes for acidophilic spherulocytes and spheruloctyes, in which the cells maintained the general profile, but varied in the size of their spherules (Figures 7, 8, and S1). The morphotypes of both spherule cells were grouped in four general categories, M1-M4, ranging from cells with small spherules to cells with large and obvious spherules.

In acidophilic spherulocytes (Figure 7), these morphotypes could be identified based on the appearance of cytoplasmic granules. Cells comprising M1 had the largest nucleus, high NCR (Figure 9B,C), and a smooth cytoplasm (Figure 7A-C), whereas cells in $M 2$ had a smaller nucleus, lower NCR (Figure 9B,C), and more granular cytoplasm but without individualized spherules (Figure 7D-F). Cells in M3 had an even smaller nucleus diameter and NCR (Figure 9B,C), and the cytoplasm was composed of individualized spherules (Figure 7G-I). Cells belonging to $\mathrm{M} 4$ had the smallest nucleus, lowest NCR, and cytoplasm filled with iridescent and completely formed spherules, larger than in M3 (Figures 7J-L and 9B-D).

In the spherulocytes, the morphotypes followed the general sequence observed in the acidophilic spherulocytes, but they differed mainly in the presence and size of the spherules (Figures 8 and 9). In these morphotypes, the cytoplasm and nucleus diameters, as well as $\mathrm{NCR}$, were similar among stages (Figure 9E-G), whereas spherule diameter was considerably different (Figure 9H). Cells in M1 had a finely granular cytoplasm, composed only of small granules (Figures 8A-C). In M2-M4, we observed that these small granules were packed inside spherules that became progressively larger (Figures 8D-L). The morphology of all morphotypes observed in stained preparations was confirmed in SEM analyses (Figure S1). Morphological variations were not observed in morula cells.
The two-way ANOVA confirmed the differences observed in the morphometry of the different morphotypes (Table S2). In acidophilic spherulocytes, cytoplasm, nucleus, and spherule diameter were significantly associated with morphotype, species, and the interaction of these two factors (Table 5), whereas NCR was associated only with morphotype (Table 5). By contrast, in spheruloctyes, only the cytoplasm was significantly associated with morphotype, species, and with the interaction of these two factors (Table 5). The nucleus was significantly associated with species, and the NCR was affected by morphotype (Table 5). Lastly, the diameter of the spherules in the spheruloctyes was affected only by morphotype (Table 5).

\section{4 | DISCUSSION}

The sea cucumbers $H$. grisea, $H$. arenicola, and $H$. tubulosa are important species in the regions in which they occur. In addition to their ecological relevance (e.g., Ahmed et al., 2017; Warnau et al., 2006), they also have high economic potential, either as fishery resources (e.g., Junior et al., 2017; Purcell et al., 2012) or as a source of biologically active compounds (e.g., Luparello et al., 2019; Moura et al., 2015). Even so, except for $H$. tubulosa, their coelomocytes have not been explored at all. In the present study, through an integrative approach, we performed a comparative evaluation of their coelomocytes. We observed for the first time that, in general, the cells of these species are very similar, even among species showing distinct geographical distribution and ecological niches. We also revealed that an integrative approach is very useful to address cell diversity (mainly regarding spherule cells), as well as to perform comparative studies in Holothuroidea. Lastly, signals of a putative maturation process were observed in acidophilic spherulocytes and spherulocytes of all species.

Here, we focused on correlating the morphology of the living cells with that observed in cytospin preparations. We observed that when associated with other methods, such as cytochemistry or SEM, cytocentrifugation can provide better identification through morphological, morphometric, and biochemical or cytochemical data. Nevertheless, its use without comparisons with live cells can lead to confusing results. For example, a recent study using cytospins (Taguchi et al., 2016) reported 12 cell types for Apostichopus japonicus. However, seven to nine coelomocytes have been customarily described for this species (Gao \& Yang, 2015; Li et al., 2018; Xing et al., 2008). Because data for live cells were not shown in the study by Taguchi et al. (2016), it is difficult to analyze the reasons for the higher cell diversity observed in A. japonicus. This could be due to the identification of new cell types, different morphotypes of a specific subpopulation or preparation artifacts. Thus, we recommend that studies using cytocentrifugation should always combine the observation of stained and live cells to limit or avoid misinterpretations about cell types.

Five ubiquitous, general cell categories (i.e., phagocytes, fusiform cells, spherule cells, progenitor cells, and crystal cells) were found in the coelomic fluid of $\mathrm{H}$. grisea, $\mathrm{H}$. arenicola, and $\mathrm{H}$. tubulosa. The DCC of some cell types varied among species, possibly as a consequence of their particular ecological, physiological, and/or reproductive state. 


\section{H. grisea}
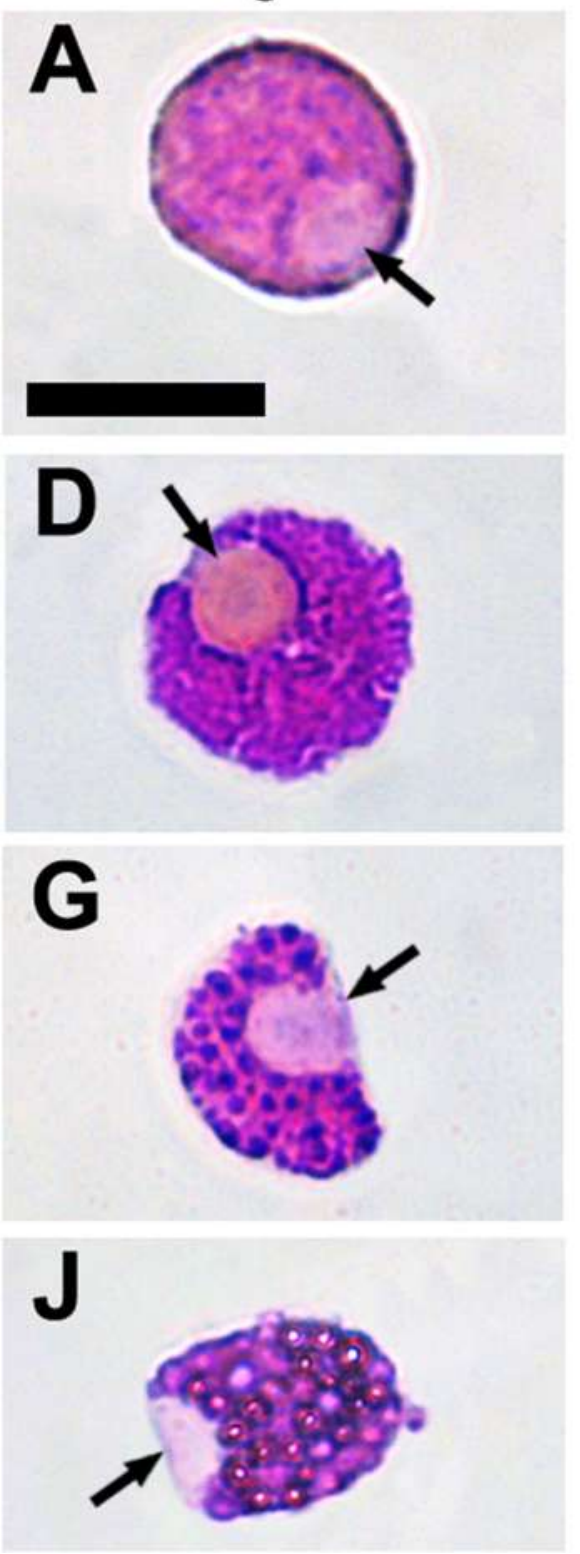

H. arenicola
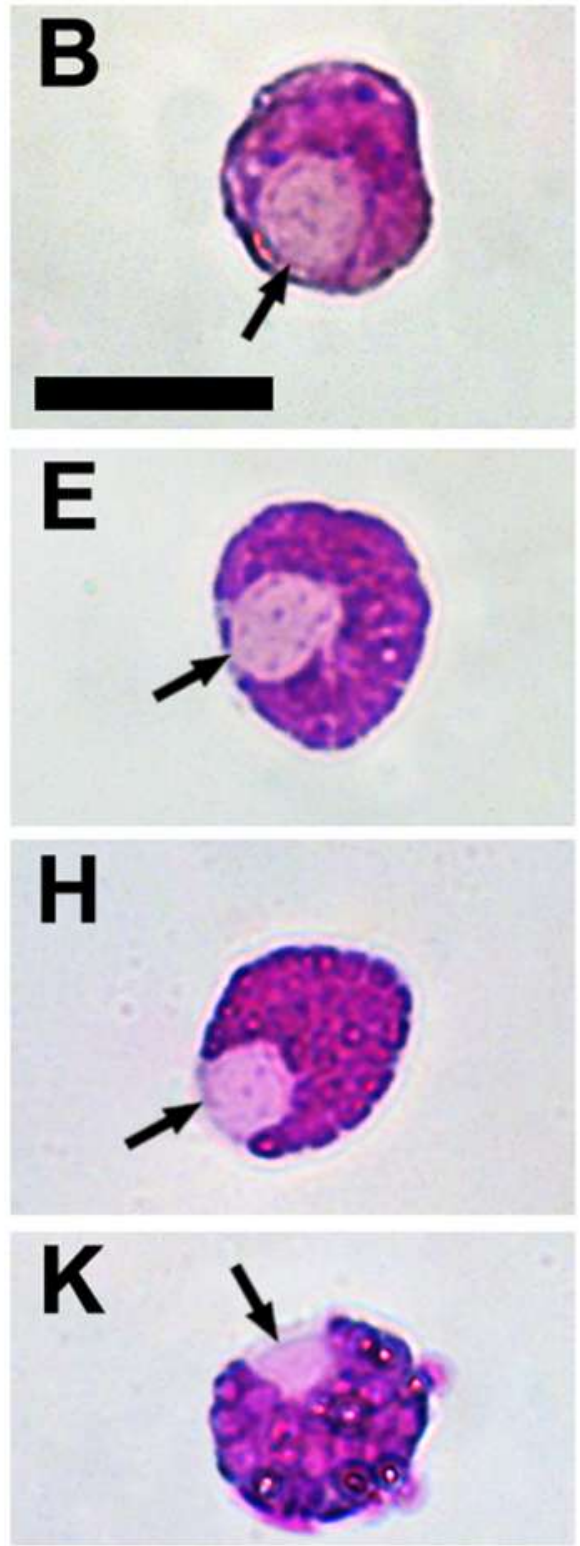

H. tubulosa
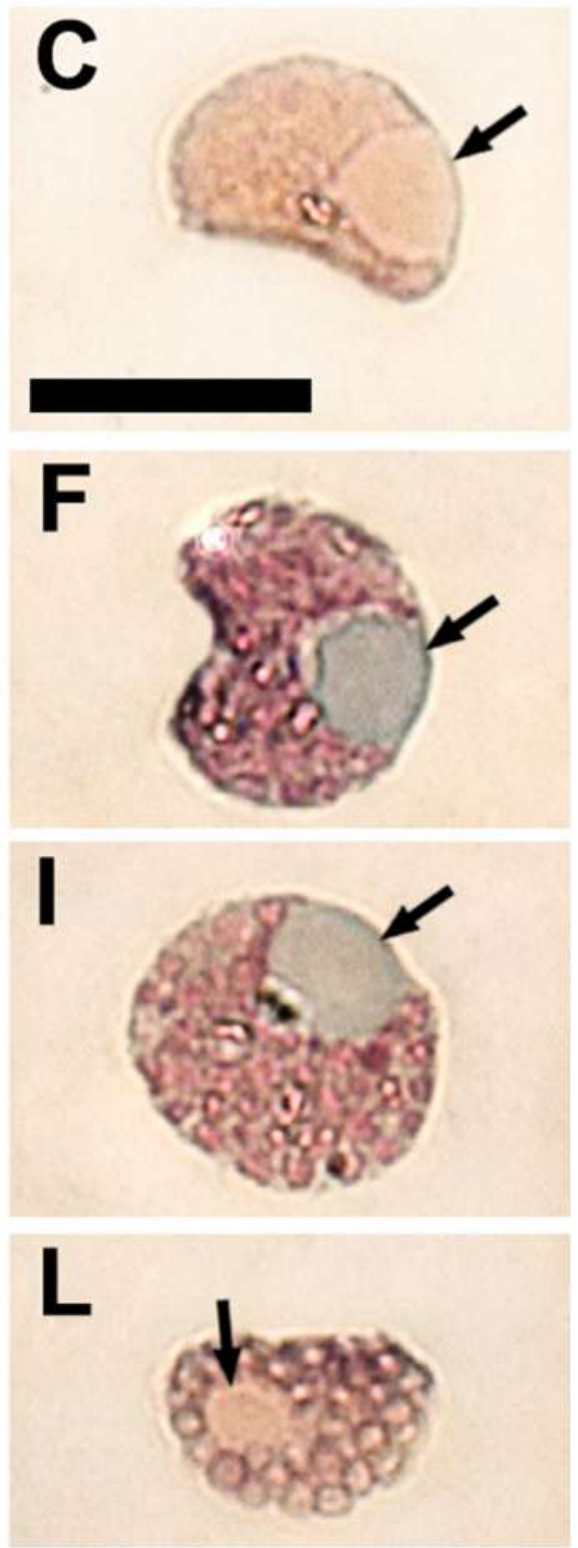

FIGURE 7 Morphotypes of acidophilic spherulocytes of Holothuria grisea, H. arenicola, and H. tubulosa, stained with Mallory's trichrome. A-C. Morphotype 1 (M1). D-F. Morphotype 2 (M2). G-I. Morphotype 3 (M3). J-L. Morphotype 4 (M4). Arrows indicate nucleus. Scale = $10 \mu \mathrm{m}$

However, all were consistently similar regarding their morphological, morphometric, and cytochemical characteristics, regardless of the species analyzed. Except for the morphology of living cells, which compared well with previous studies (e.g., Endean, 1958; Hetzel, 1963), comparison of our data with other studies is difficult because of differences in methods. Although other studies of coelomocytes in Holothuroidea have also analyzed morphometrics (Prompoon et al., 2015; Ramírez-Gómez et al., 2010) and cell morphology of stained (D'Ancona \& Canicattì, 1990; Prompoon et al., 2015; RamírezGómez et al., 2010) and SEM (Xing et al., 2008; Bello et al., 2015) preparations, these studies commonly use smeared cells instead cytocentrifugation. Taking into account that coelomocyte morphology, and consequently morphometry, may be affected by biotic or abiotic factors in smeared preparations (e.g. Canicattí et al., 1989b; Branco et al., 2013), comparisons with other studies are limited.

Considering all species of the genus Holothuria in which the coelomocytes were studied (Table S3), eight cell types were already known (see also Canicatti \& Quaglia, 1991; Canicatti et al., 1988, 1992; Jans et al., 1995; Millot, 1953). However, the presence of some types is still controversial. The identity of lymphocytes versus progenitor cells is still under debate in Holothuroidea (e.g., Elisenkina \& Magarlamov, 2002; Fontaine \& Lambert, 1977), as observed in Holothuria species (Prompoon et al., 2015; Vazzana et al., 2015). Although cells morphologically similar to lymphocytes or progenitor cells have been described in all studied species in the genus, the lack of consensus on the role of this cell type as immune 


\section{H. grisea}

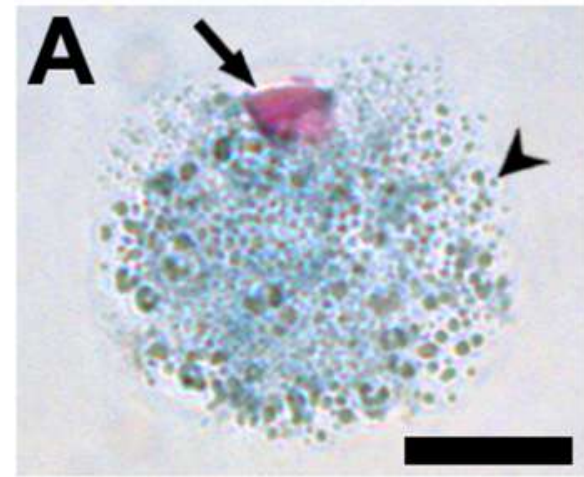

\section{D}

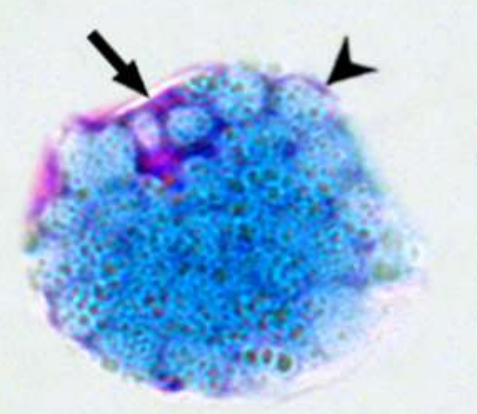

G

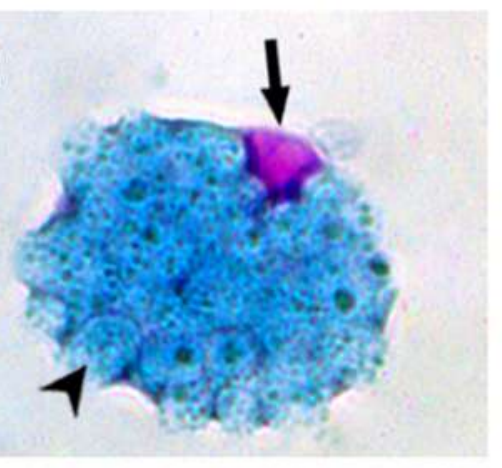

J

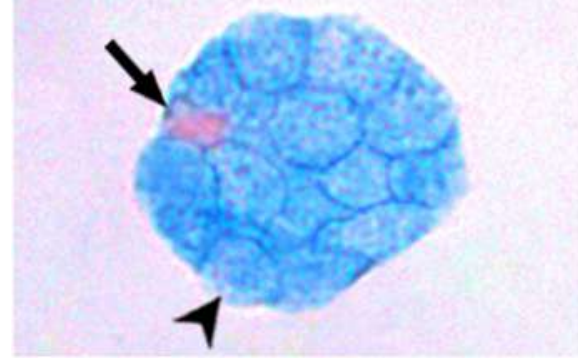

H. arenicola
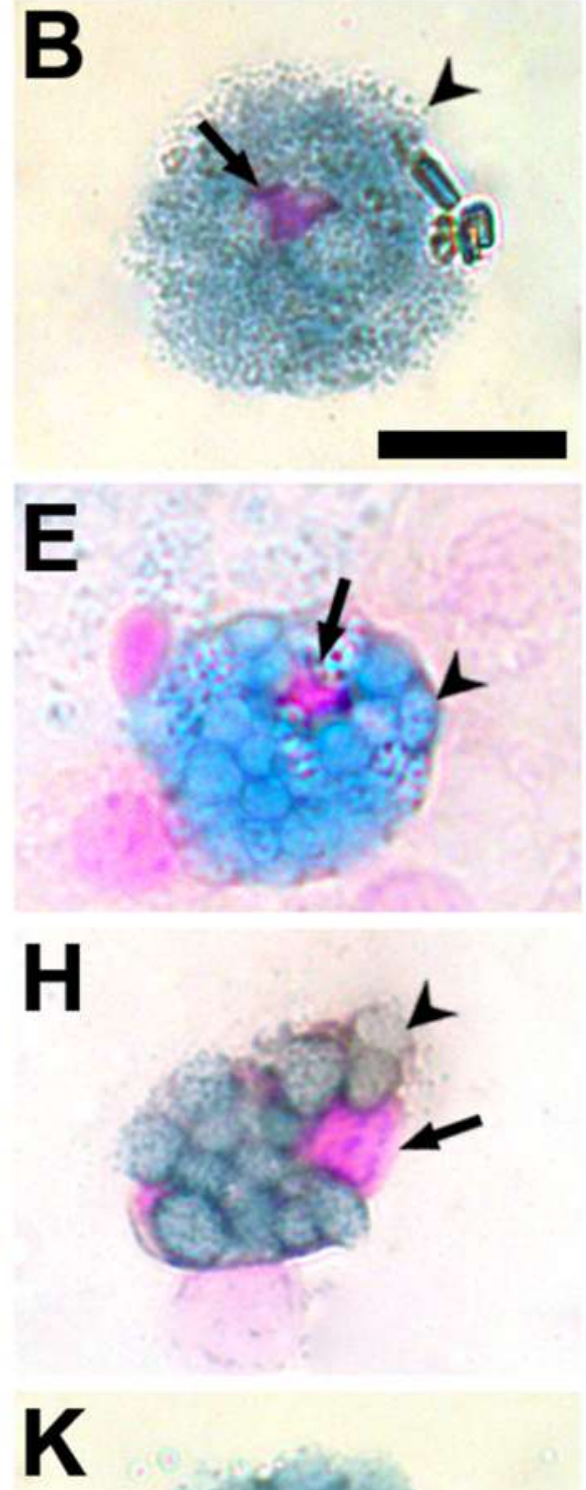

K

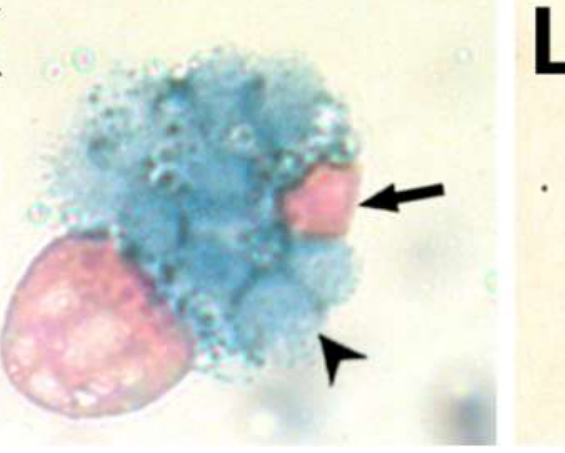

H. tubulosa
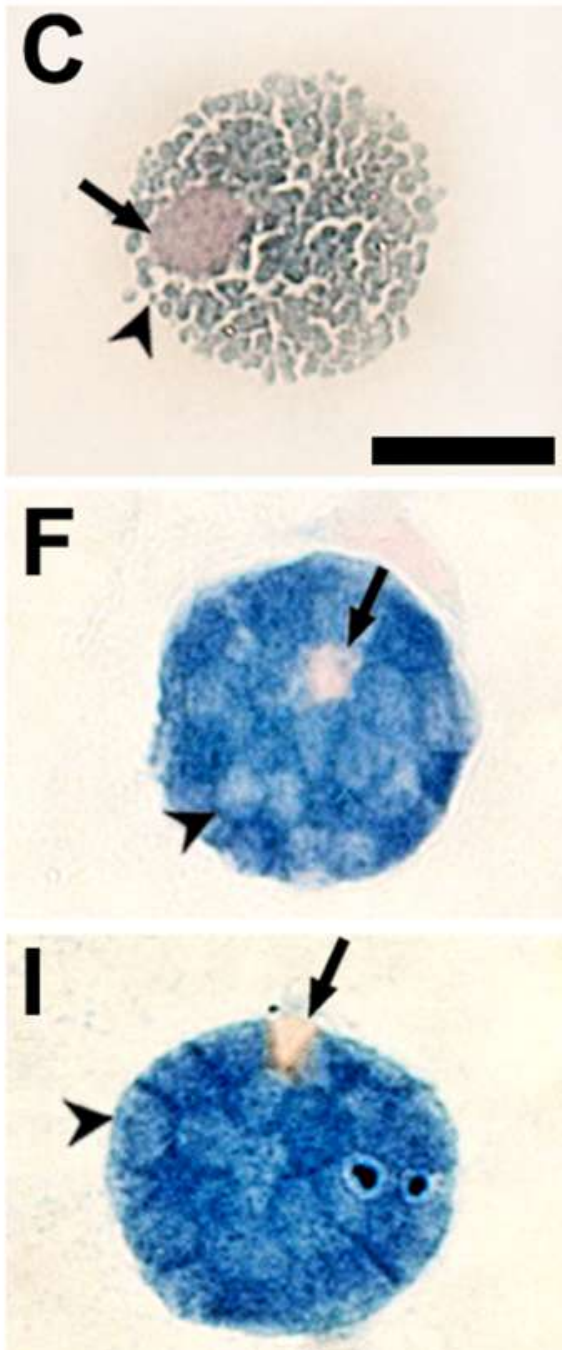

L

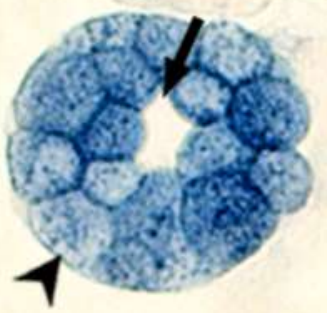

FIGURE 8 Morphotypes of spherulocytes of Holothuria grisea, H. arenicola, and H. tubulosa stained with Mallory's trichrome. A-C. Morphotype 1 (M1). D-F. Morphotype 2 (M2). G-I. Morphotype 3 (M3). J-L. Morphotype 4 (M4). Arrows indicate nucleus; arrowheads indicate cytoplasmic spherule. Scale $=10 \mu \mathrm{m}$

effector or proliferative cell affects a complete understanding of this type of coelomocyte. Giant cells were previously described only for stained preparations (Prompoon et al., 2015; Ramírez-Gómez et al., 2010), similar to the present study. The absence of this cell type in live preparations, along with its very wide and variable diameter, as well as its $\beta$-metachromatic cytoplasm in TB preparations, suggests that this cell may be a preparation artifact (possibly a damaged morula cell in which the cytoplasm has leaked) instead of a distinct cell type. Lastly, the literature review on species of Holothuria showed that vibratile cells were observed only in 
Acidophilic spherulocyte
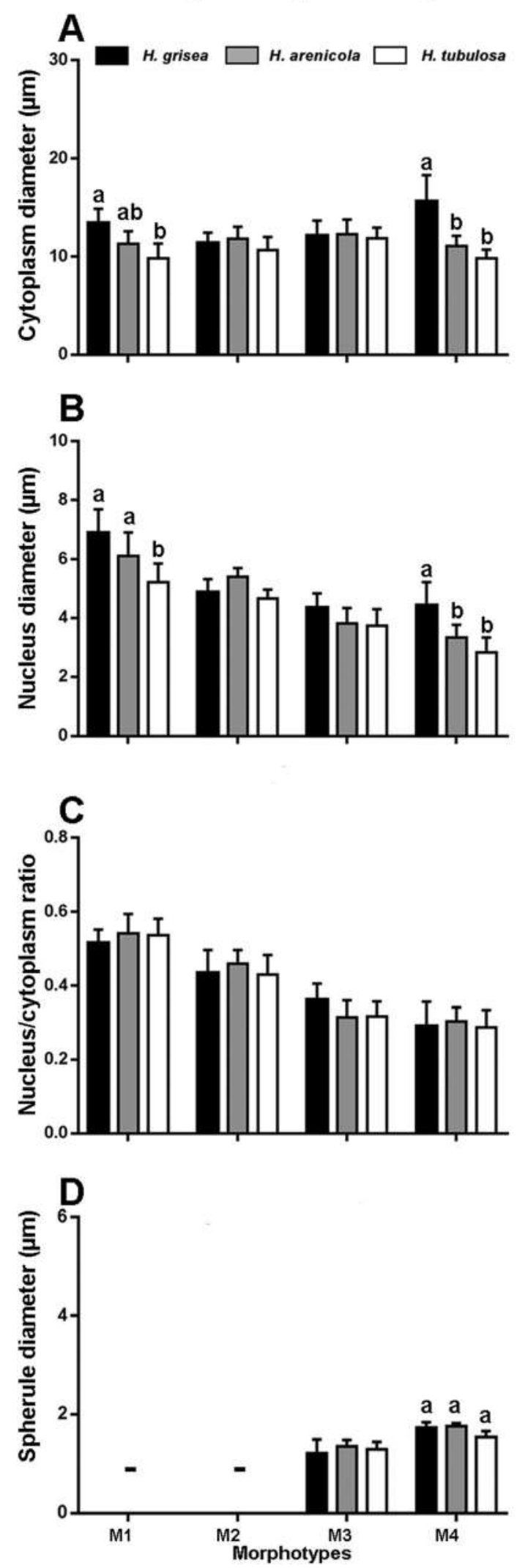

\section{Spherulocyte}
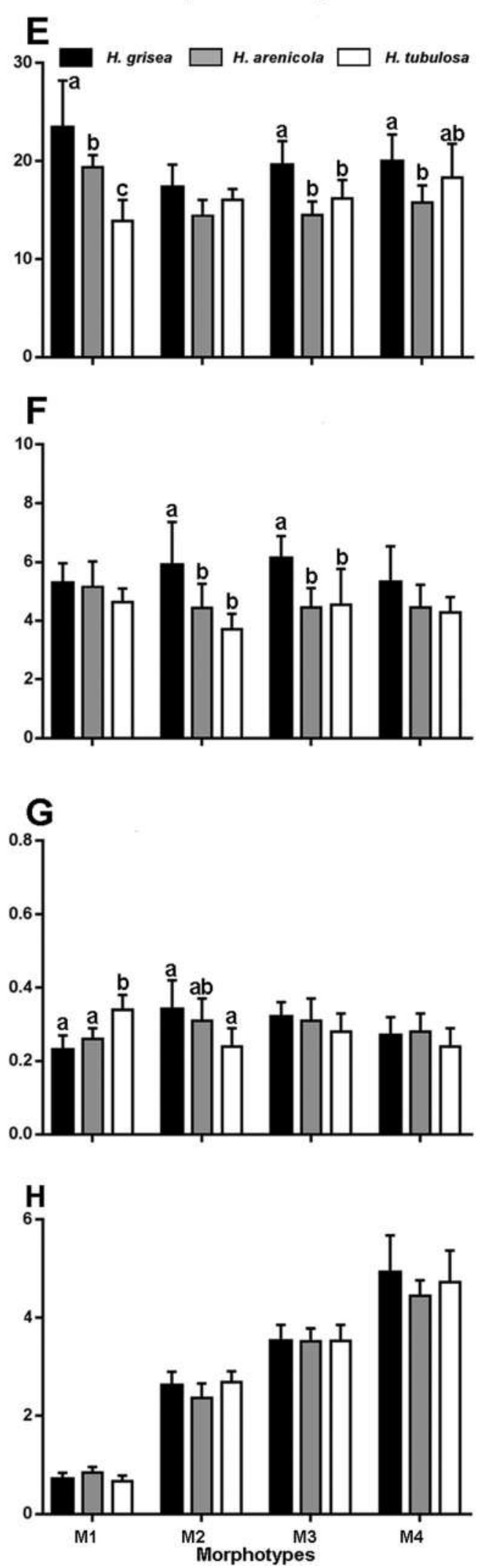

FIGURE 9 Morphometric parameters of the stained morphotypes (M1-M4) of the acidophilic spherulocytes and spherulocytes of Holothuria grisea, $H$. arenicola, and H. tubulosa. Different letters indicate significant differences $(p<.05)$ among species of the same morphotype in two-way analysis of variance (ANOVA) analyses. Differences among morphotypes are shown in Table S1. Error bars represent the standard deviation of the mean. Hyphens indicate that spherules were not found 
TAB LE 5 Summary table of two-way ANOVA applied to the measurements of different morphotypes of acidophilic spherulocytes and spherulocytes

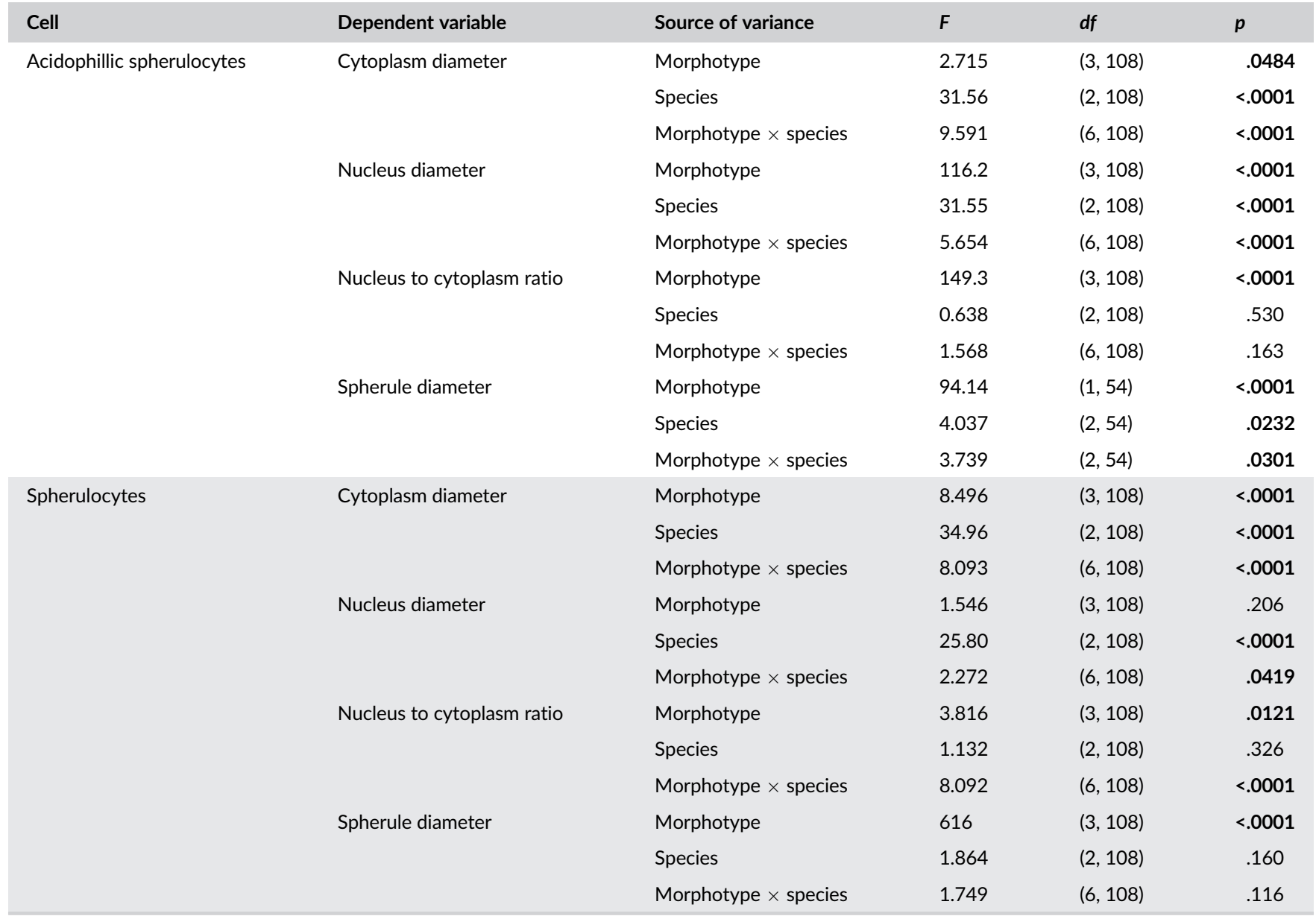

Note: Bold $p$ values are statistically significant $(p<.05)$.

H. glaberrima (Ramírez-Gómez et al., 2010). According to Hetzel (1963), vibratile cells could be contaminants or symbiotic protozoa. If this is true, it is possible that a careful cleaning of the external surface of the specimens before coelom collection, as carried out here, will avoid such contaminants.

Even though spherule cells are not the most representative coelomocyte in Holothuroidea (e.g., Vazzana et al., 2015; Xing et al., 2008), they comprise an important cell type. In the present study, three subpopulations were observed, which differed consistently in spherule diameter and cytochemistry. Despite the variable number of subpopulations recorded in Holothuria (one to three; Endean, 1958; Jans \& Jangoux, 1990; Vazzana et al., 2015), two subtypes have been commonly mentioned. For example, although only "morula-shaped cells" have been recorded in $H$. leucospilota, the author mentions the presence of "larger and smaller" subtypes (Endean, 1958). By contrast, three subpopulations were reported in H. poli and H. tubulosa (Canicattì et al., 1989b; Vazzana et al., 2015). Regardless of the name, most studies have reported that one subtype comprises larger cells, crowded with large and irregular spherules, whereas the other comprises smaller cells filled with smaller spherules (Canicattì et al., 1989; Jans \& Jangoux, 1990; Vazzana et al., 2015).
Occasionally, a third type is mentioned, but its morphology varies across studies (e.g., Canicattì et al., 1989; Vazzana et al., 2015). Canicattì et al. (1989), using semithin sections, observed that in $\mathrm{H}$. poli, the third type (which they termed "Type III spherule cell") contained empty vacuoles; Vazzana et al. (2015), through analysis of smeared cells of $H$. tubulosa, observed a finely granular cell (which they termed "spherulocyte"). We also observed a third cell type in $H$. grisea, $H$. arenicola, and $H$. tubulosa, which is consistent with the spherulocyte described by Vazzana et al. (2015). As this third type observed here showed consistent morphology and morphometry, even when observed under different methods, the idea that it could be a preparation artifact-as raised by Canicattì et al. (1989) for the "Type III spherule cell" of H. poli-can be discarded. Even so, Holothuroidea spherule cells deserve further study to unravel their real diversity.

Morphometric data were useful to discriminate the coelomocytes of all three species, mainly the spherule cells, and helped us to observe that (1) cellular characteristics were consistent among the species analyzed; (2) in addition to morphology and stain affinity, spherule cells could be distinguished based on the size of their spherules. Still, morphometry was indispensable to confirm the differences in cellular characteristics among different morphotypes of acidophilic 
spherulocytes and spherulocytes. Morphometry has been a useful parameter to discriminate coelomocytes or hemocytes in Bivalvia (Mollusca), Orthoptera, and Lepidoptera (Insecta) (Falleiros et al., 2003; Öztürk et al., 2018; Salimi et al., 2009) and may also be a useful tool to address the health status of invertebrates, as observed in studies of mollusks (Calisi et al., 2008; Carella et al., 2017). Although some studies on Holothuroidea have provided cell measurements (e.g., Prompoon et al., 2015; Xing et al., 2008), as far as we know our study is the first to provide detailed morphometric comparisons, as well as morphometric parameters that allows for the identification of different spherule cells.

In addition to the different spherule cell subtypes found in the three species studied herein, we also observed that the morphology of some cell subpopulations (i.e., acidophilic spherulocytes and spherulocytes) can be even more complex (Figures 6 and 7). Though morphological characteristics are similar, morphometric analyses showed considerable differences among morphotypes, mainly with regard to spherule size (Table S1). Previous studies have recorded that hemocytes or coelomocytes in crustaceans and mollusks may show subtle but consistent morphological differences (e.g., Battison et al., 2003; Rebelo et al., 2013), and this was also observed in Echinodermata (Elisenkina \& Magarlamov, 2002; Endean, 1958; Queiroz \& Custódio, 2015). In echinoderms, it has been suggested that these morphological differences represent a maturation process. For example, Endean (1958), studying live cells, also described "transitional stages from homogeneous amoebocyte to morula-shaped cell" in H. leucospilota. Elisenkina and Magarlamov (2002), in a study of TEM preparations, proposed that coelomocytes undergo a maturation process in A. japonicus and Cucumaria japonica. In addition, in a study of cytochemical and TEM preparations, Queiroz and Custódio (2015) corroborated a putative maturation process in the echinoid Eucidaris tribuloides. Although our morphological and morphometric data support the possibility that coelomocytes undergo a maturation process, as proposed in other works (Elisenkina \& Magarlamov, 2002; Queiroz \& Custódio, 2015), the few cells analyzed here prevent a detailed analysis of different maturation stages. Thus, we emphasize the need for further studies to unravel this particular issue.

\section{5 | CONCLUSION}

The integrative approach focusing on cytospin preparations used here was essential to perform the comparative study of the coelomocytes of $H$. grisea, $H$. arenicola, and $H$. tubulosa. Cytocentrifugation allowed the following: (1) the observation of a large number of cells in a single field, similar to living cell preparations; (2) the obtaining of consistent measurements, because cell morphology remains stable in cytospins (Queiroz et al., 2021); (3) the observation of morphological and cytochemical aspects of cells, similar to transmission electron microscopy analyses. Furthermore, the use of cytocentrifugation allowed the confirmation of three types of spherule cells in the studied species, as well as the observation of a set of morphotypes that may indicate a putative maturation process. Specific cell markers are not available to identify echinoderm spherule cells and thus a morphological and morphometric approach has been the only available method to address this question. We also observed that, although the species analyzed here inhabit different ecoregions and have different ecological requirements, their coelomocytes are consistently similar with respect to their morphology, morphometry, cytochemistry, and relative proportions (TCC and DCC).

Thus, as a contribution to the knowledge of holothurian coelomocytes (and consequently to Echinodermata as a whole), our study demonstrates that there are still some basic aspects-such as the actual number of different types of spherule cells, their function, and the existence of a maturation process in these cells-that deserve further attention. Certainly, a better understanding of echinoderm coelomocytes is important, because these cells can be used as bioindicators of health in wild and cultured echinoderms (Galimany et al., 2018; Queiroz, 2020), as well as a source of biologically active compounds (e.g., Luparello et al., 2019) for the pharmaceutical industry.

\section{ACKNOWLEDGMENTS}

The authors thank Prof. Dr. Suzana T.C. Lima (Labbiotec - UFBA) for support during collections and preliminary analyses of $H$. arenicola, and Márcio V. Cruz, for support with SEM analyses. We also thank Dr. Giampaolo Badalamenti for his collaboration in the collections and management of individuals of $H$. tubulosa used in the experiments and Daniel C. Cavallari for English improvements. Vincenzo Arizza and Mirella Vazzana Personally thank Fondo Finalizzato alla Ricerca di Ateneo (FFR, 2018-2021) for financial support. This work was supported by FAPESP (Grant numbers: 2015/21460-5 and 2018/ 14497-8). This is a contribution of NP-BioMar (Research Center for Marine Biodiversity - USP).

\section{CONFLICT OF INTEREST}

The authors declare that they have no known competing financial interests or personal relationships that could have appeared to influence the work reported in this paper.

\section{ORCID}

Vinicius Queiroz (DD https://orcid.org/0000-0002-0764-9975

\section{REFERENCES}

Ahmed, Q., Ali, Q. M., \& Bat, L. (2017). Assessment of heavy metals concentration in Holothurians, sediments and water samples from coastal areas of Pakistan (northern Arabian Sea). Journal of Coastal Life Medicine, 5(5), 191-201. https://doi.org/10.12980/jclm.5.2017J7-56

Balaneva, N. N., Shestak, O. P., Anufriev, V. F., \& Novikov, V. L. (2016). Synthesis of spinochrome $D$, a metabolite of various sea-urchin species. Chemistry of Natural Compounds, 52(2), 213-217. https://doi.org/ 10.1007/s10600-016-1597-4

Battison, A., Cawthorn, R., \& Horney, B. (2003). Classification of Homarus americanus hemocytes and the use of differential hemocyte counts in lobsters infected with Aerococcus viridans var. homari (Gaffkemia). Journal of Invertebrate Pathology, 84(3), 177-197. https://doi.org/10. 1016/j.jip.2003.11.005

Bello, S. A., Abreu-Irizarry, R. J., \& García-Arrarás, J. E. (2015). Primary cell cultures of regenerating Holothurian tissues. In C. M. Nelson (Ed.), Tissue morphogenesis: Methods and protocols, methods in molecular biology (pp. 283-297). Springer. https://doi.org/10.1007/978-1-4939-1164-6_19 
Borrero-Pérez, G. H., Gómez-Zurita, J., González-Wangüemert, M., Marcos, C., \& Pérez-Ruzafa, A. (2010). Molecular systematics of the genus Holothuria in the Mediterranean and northeastern Atlantic and a molecular clock for the diversification of the Holothuriidae (Echinodermata: Holothuroidea). Molecular Phylogenetics and Evolution, 57(2), 899-906. https://doi.org/10.1016/j.ympev.2010.08.019

Branco, P. C., Borges, J. C. S., Santos, M. F., Junior, B. E. J., \& Silva, J. R. M. C. (2013). The impact of rising sea temperature on innate immune parameters in the tropical subtidal sea urchin Lytechinus variegatus and the intertidal sea urchin Echinometra lucunter. Marine Environmental Research, 92, 95-101. https://doi.org/10.1016/j.marenvres.2013.09.005

Calisi, A., Lionetto, M. G., Caricato, R., Giordano, M. E., \& Schettino, T. (2008). Morphometric alterations in Mytilus galloprovincialis granulocytes: A new biomarker. Environmental Toxicology and Chemistry, 27(6), 1435-1441. https://doi.org/10.1897/07-396.1

Canicatti, C., \& Quaglia, A. (1991). Ultrastructure of Holothuria polii encapsulating body. Journal of Zoology, 224(3), 419-429. https://doi.org/10. 1111/j.1469-7998.1991.tb06035.x

Canicatti, C., Ciulla, D., \& Farinalipari, E. (1988). The hemolysin-producer coelomocytes in Holothuria polii. Developmental and Comparative Immunology, 12(4), 729-736. https://doi.org/10.1016/0145-305X(88) 90048-1

Canicattì, C., D'Ancona, G., \& Farina-Lipari, E. (1989a). The Holothuria polii brown bodies. The Italian Journal of Zoology, 56(4), 275-283. https:// doi.org/10.1080/11250008909355651

Canicattì, C., D'Ancona, G., \& Farina-Lipari, E. (1989b). The coelomocytes of Holothuria polii (Echinodermata). I. Light and electron microscopy. The Italian Journal of Zoology, 56, 29-36. https://doi.org/10.1080/ 11250008909355618

Canicatti, C., Rizzo, A., \& Montinari, M. R. (1992). Adhesive properties of sea cucumber coelomocytes. Biology of the Cell, 76(1), 97-102. https://doi.org/10.1016/0248-4900(92)90199-B

Carella, F., De Vico, G., \& Landini, G. (2017). Nuclear morphometry and ploidy of normal and neoplastic haemocytes in mussels. PLOS ONE, 12(3), e0173219. https://doi.org/10.1371/journal.pone.0173219

Caulier, G., Hamel, J. F., \& Mercier, A. (2020). From coelomocytes to colored aggregates: Cellular components and processes involved in the immune response of the holothuroid Cucumaria frondosa. Biological Bulletin, 239(2), 95-114. https://doi.org/10.1086/710355

Chiaramonte, M., Arizza, V., La Rosa, S., Queiroz, V., Mauro, M., Vazzana, M., \& Inguglia, L. (2020). Allograft inflammatory factor AlF-1: Early immune response in the Mediterranean sea urchin Paracentrotus lividus. Zoology, 142, 125815. https://doi.org/10.1016/j.zool.2020.125815

D'Ancona, G., \& Canicattì, C. (1990). The coelomocytes of Holothuria poli (Echinodermata) II. Cytochemical staining properties. Basic and Applied Histochemistry, 34, 209-218.

Elisenkina, M. G., \& Magarlamov, T. Y. (2002). Coelomocyte morphology in the holothurians Apostichopus japonicus (Aspidochirota: Stichopodidae) and Cucumaria japonica (Dendrochirota: Cucumariidae). Russian Journal of Marine Biology, 28, 197-202. https://doi.org/10.1023/A: 1016801521216

Endean, R. (1958). The coelomocytes of Holothuria leucospilota. Journal of Cell Science, 3(45), 47-60. https://doi.org/10.1242/jcs.s3-99.45.47

Falleiros, Â. M. F., Bombonato, M. T. S., \& Gregório, E. A. (2003). Ultrastructural and quantitative studies of hemocytes in the sugarcane borer, Diatraea saccharalis (Lepidoptera: Pyralidae). Brazilian Archives of Biology and Technology, 46(2), 287-294. https://doi.org/10.1590/ S1516-89132003000200021

Fontaine, A. R., \& Lambert, P. (1977). The fine structure of the leucocytes of the holothurian, Cucumaria miniata. Canadian Journal of Zoology, 55(9), 1530-1544. https://doi.org/10.1139/z77-198

Galimany, E., Baeta, M., \& Ramón, M. (2018). Immune response of the sea cucumber Parastichopus regalis to different temperatures: Implications for aquaculture purposes. Aquaculture, 497, 357-363. https://doi.org/ 10.1016/j.aquaculture.2018.08.005
Gao, F., \& Yang, H. (2015). Anatomy. In H. Yang, J. F. Hamel, \& A. Mercier (Eds.), The sea cucumber Apostichopus japonicus: History, biology, and aquaculture (pp. 53-76). Academic Press.

Hendler, G., Miller, J. E., Pawson, D. L., \& Kier, P. M. (1995). Echinoderms of Florida and the Caribbean: Sea stars, sea urchins, and allies. Smithsonian Institution.

Hetzel, H. R. (1963). Studies on holothurian coelomocytes. I. A survey of coelomocyte types. Biological Bulletin, 125(2), 289-301. https://doi. org/10.2307/1539404

Ho, E. C. H., \& Rast, J. P. (2016). The immune system of echinoderms. In W. Hein, J. R. Gordon, C. J. Guidos, \& A. Rolink (Eds.), Encyclopedia of immunobiology (Vol. 1) (pp. 462-467). Elsevier. https://doi.org/10. 1016/b978-0-12-374279-7.12007-7

Inguglia, L., Chiaramonte, M., di Stefano, V., Schillaci, D., Cammilleri, G., Pantano, L., Mauro, M., Vazzana, M., Ferrantelli, V., Nicolosi, R., \& Arizza, V. (2020). Salmo salar fish waste oil: Fatty acids composition and antibacterial activity. PeerJ, 8, e9299. https://doi.org/10.7717/peerj.9299

Jans, D., Dubois, P., \& Jangoux, M. (1995). Defensive mechanisms of holothuroids (Echinodermata): Formation, role, and fate of intracoelomic brown bodies in the sea cucumber Holothuria tubulosa. Cell and Tissue Research, 283, 99-106. https://doi.org/10.1007/ s004410050517

Jans, D., \& Jangoux, M. (1990). Structure fine des spherulocytes de l'holothuride Holothuria tubulosa (Echinodermata). In C. De Ridder, P. Dubois, M. C. Lahaye, \& M. Jangoux (Eds.), Echinoderm research (pp. 261-267). A.A. Balkema.

Junior, J. S., Ponte, I., Coe, C. M., Farias, W. R. L., Feitosa, C. V., Hamel, J. F., \& Mercier, A. (2017). Sea cucumber fisheries in northeast Brazil. SPC Beche-de-Mer Information Bulletin, 37, 43-47.

Kamyab, E., Kellermann, M. Y., Kunzmann, A., \& Schupp, P. J. (2019). Chemical biodiversity and bioactivities of saponins in echinodermata with an emphasis on sea cucumbers (Holothuroidea). In S. Jungblut, V. Liebich, \& M. Bode-Dalby (Eds.), YOUMARES 9-the oceans: Our research, our future (pp. 121-157). Springer.

Kazanidis, G., Antoniadou, C., Lolas, A. P., Neofitou, N., Vafidis, D., Chintiroglou, C., \& Neofitou, C. (2010). Population dynamics and reproduction of Holothuria tubulosa (Holothuroidea: Echinodermata) in the Aegean Sea. Journal of the Marine Biological Association of the United Kingdom, 90(5), 895-901. https://doi.org/10.1017/S0025315410000251

Lazzara, V., Arizza, V., Luparello, C., Mauro, M., \& Vazzana, M. (2019). Bright spots in the darkness of cancer: A review of starfishes-derived compounds and their anti-tumor action. Marine Drugs, 17, 617. https://doi.org/10.3390/md17110617

Li, Q., Ren, Y., Liang, C., Qiao, G., Wang, Y., Ye, S., \& Li, R. (2018). Regeneration of coelomocytes after evisceration in the sea cucumber, Apostichopus japonicus. Fish \& Shellfish Immunology, 76, 266-271. https://doi.org/10.1016/j.fsi.2018.03.013

Luparello, C., Mauro, M., Arizza, V., \& Vazzana, M. (2020). Histone deacetylase inhibitors from marine invertebrates. Biology, 9(2), 429. https://doi.org/10.3390/biology9120429

Luparello, C., Mauro, M., Lazzara, V., \& Vazzana, M. (2020). Collective locomotion of human cells, wound healing and their control by extracts and isolated compounds from marine invertebrates. Molecules, 25(11), 2471. https://doi.org/10.3390/molecules25112471

Luparello, C., Ragona, D., Asaro, D. M. L., Lazzara, V., Affranchi, F., Celi, M., Arizza, V., \& Vazzana, M. (2019). Cytotoxic potential of the coelomic fluid extracted from the sea cucumber Holothuria tubulosa against triple-negative MDA-MB231 breast cancer cells. Biology, 8(4), 76. https://doi.org/10.3390/biology8040076

Massin, C., \& Jangoux, M. (1976). Observations ecologiques sur Holothuria tubulosa, $\mathrm{H}$. poli et $\mathrm{H}$. forskali (Echinodermata: Holothuroidea) et comportement alimentaire de $H$. tubulosa. Cahiers de Biologie Marine, 17, 45-59.

Matranga, V., Pinsino, A., Celi, M., Natoli, A., Bonaventura, R., Schröder, H. C., \& Müller, W. E. G. (2005). Monitoring chemical and physical stress using sea urchin immune cells. In V. Matranga (Ed.), 
Echinodermata. Progress in molecular and subcellular biology (marine molecular biotechnology) (pp. 85-543). Springer.

Mauro, M., Lazzara, V., Punginelli, D., Arizza, V., \& Vazzana, M. (2020). Antitumoral compounds from vertebrate sister group: A review of Mediterranean ascidians. Developmental and Comparative Immunology, 108, 103669. https://doi.org/10.1016/j.dci.2020.103669

Mauro, M., Pérez-Arjona, I., Belda Perez, E. J., Ceraulo, M., Bou-Cabo, M., Benson, T., Espinosa, V., Beltrame, F., Mazzola, S., Vazzana, M., \& Buscaino, G. (2020). The effect of low-frequency noise on the behavior of juvenile Sparus aurata. Journal of the Acoustical Society of America, 147(6), 3795-3807. https://doi.org/10.1121/10.0001255

Mauro, M., Queiroz, V., Arizza, V., Campobello, D., Custódio, M. R., Chiaramonte, M., \& Vazzana, M. (2021). Humoral responses during wound healing in Holothuria tubulosa (Gmelin, 1788). Comparative Biochemistry \& Physiology Part B: Biochemical and Molecular Biology, 253, 110550. https://doi.org/10.1016/j.cbpb.2020.110550

Millot, N. (1953). Observations of the skin pigment and amoebocytes, and the occurrence of phenolases in the coelomic fluid of Holothuria forskali Delle Chiaje. Journal of the Marine Biological Association of the United Kingdom, 31(3), 529-539. https://doi.org/10.1017/S0025315400011693

Moura, R. M., Melo, A. A., Carneiro, R. F., Rodrigues, C. R. F., Delatorre, P., Nascimento, K. S., Saker-Sampaio, S., Nagano, C. S., Cavada, B. S., \& Sampaio, A. H. (2015). Hemagglutinating/hemolytic activities in extracts of marine invertebrates from the Brazilian coast and isolation of two lectins from the marine sponge Cliona varians and the sea cucumber Holothuria grisea. Anais da Academia Brasileira de Ciências, 87(2), 973-984. https://doi.org/10.1590/0001-3765201520140399

Öztürk, G., Çakici, Ö., \& Arikan, H. (2018). Morphological characterization of hemocyte types in some species belonging to Tettigoniidae and Pamphagidae (Insecta: Orthoptera). Turkish Journal of Zoology, 42(3), 340-345.

Parisi, M. G., Mauro, M., Sarà, G., \& Cammarata, M. (2017). Temperature increases, hypoxia, and changes in food availability affect immunological biomarkers in the marine mussel Mytilus galloprovincialis. Journal of Comparative Physiology B, 187, 1117-1126. https://doi.org/10.1007/ s00360-017-1089-2

Pawson, D. L. (2007). Phylum Echinodermata. Zootaxa, 1668, 749-764. https://doi.org/10.11646/zootaxa.1668.1.31

Pinsino, A., Thorndyke, M. C., \& Matranga, V. (2007). Coelomocytes and post-traumatic response in the common sea star Asterias rubens. Cell Stress \& Chaperones, 12(4), 331-341. https://doi.org/10.1379/csc-288.1

Pipe, R. K., \& Coles, J. A. (1995). Environmental contaminants influencing immune function in marine bivalve mollusks. Fish \& Shellfish Immunology, 5(8), 581-595. https://doi.org/10.1016/S1050-4648(95)80043-3

Prompoon, Y., Weerachatyanukul, W., Withyachumnarnkul, B., Vanichviriyakit, R., Wongprasert, K., \& Asuvapongpatana, S. (2015). Lectin-based profiling of coelomocytes in Holothuria scabra and expression of superoxide dismutase in purified coelomocytes. Zoological Science, 32(4), 345-351. https://doi.org/10.2108/zs140285

Purcell, S. W., Samyn, Y., \& Conand, C. (2012). Commercially important sea cucumbers of the world. FAO. FAO Species Catalogue for Fishery Purposes No. 6.

Queiroz, V. (2020). An unprecedented association of an encrusting bryozoan on the test of a live sea urchin: Epibiotic relationship and physiological responses. Marine Biodiversity, 50(5), 1-7. https://doi. org/10.1007/s12526-020-01108-1

Queiroz, V., Arizza, V., Vazzana, M., Rozas, H. E., \& Custódio, M. R. (2021). Cytocentrifugation as an additional method to study echinoderm coelomocytes: A comparative approach combining living cells, stained preparations, and energy-dispersive x-ray spectroscopy. Revista de Biología Tropical, 69(S1), 171-184. https://doi.org/10.15517/rbt.v69iSuppl.1.46348

Queiroz, V., \& Custódio, M. R. (2015). Characterisation of the spherulocyte subpopulations in Eucidaris tribuloides (Cidaroida: Echinoidea). The Italian Journal of Zoology, 82(3), 338-348. https://doi.org/10.1080/ 11250003.2015.1019580
Ramírez-Gómez, F., Aponte-Rivera, F., Méndez-Castaner, L., \& García-Arrarás, J. E. (2010). Changes in holothurian coelomocyte populations following immune stimulation with different molecular patterns. Fish \& Shellfish Immunology, 29(2), 175-185. https://doi.org/10.1016/j.fsi.2010.03.013

Rebelo, M. D. F., Figueiredo, E. D. S., Mariante, R. M., Nóbrega, A., Barros, C. M., \& Allodi, S. (2013). New insights from the oyster Crassostrea rhizophorae on bivalve circulating Hemocytes. PLoS ONE, 8(2), e57384. https://doi.org/10.1371/journal.pone.0057384

Salimi, L., Jamili, S., Motalebi, A., Eghtesadi-Araghi, P., Rabbani, M., \& Rostami-Beshman, M. (2009). Morphological characterization and size of hemocytes in Anodonta cygnea. Journal of Invertebrate Pathology, 101(2), 81-85. https://doi.org/10.1016/j.jip.2009.03.003

Silva, J. E. B., Boleli, I. C., \& Simões, Z. L. P. (2002). Hemocyte types and total and differential counts in unparasitized and parasitized Anastrepha obliqua (Diptera, Tephritidae) larvae. Brazilian Journal of Biology, 62(4a), 689-699. https://doi.org/10.1590/S1519-69842002000400017

Smith, V. J. (1981). The Echinoderms. In V. J. Smith (Ed.), Invertebrate blood cells (pp. 513-562). Academic Press.

Sridharan, G., \& Shankar, A. A. (2012). Toluidine blue: A review of its chemistry and clinical utility. Journal of Oral and Maxillofacial Pathology, 16(2), 251-255. https://doi.org/10.4103/0973-029X.99081

Taguchi, M., Tsutsui, S., \& Nakamura, O. (2016). Differential count and time-course analysis of the cellular composition of coelomocyte aggregate of the Japanese sea cucumber Apostichopus japonicus. Fish \& Shellfish Immunology, 58(203-590), 209.

Vazzana, M., Ceraulo, M., Mauro, M., Papale, E., Dioguardi, M., Mazzola, S., Arizza, V., Chiaramonte, M., \& Buscaino, G. (2020). Effects of acoustic stimulation on biochemical parameters in the digestive gland of Mediterranean mussel Mytilus galloprovincialis (Lamark, 1819). Journal of the Acoustical Society of America, 147(4), 2414-2422. https://doi.org/10. 1121/10.0001034

Vazzana, M., Mauro, M., Ceraulo, M., Dioguardi, M., Papale, E., Mazzola, S., Arizza, V., Beltrame, F., Ingugli, L., \& Buscaino, G. (2020). Underwater high-frequency noise: Biological responses in sea urchin Arbacia lixula (Linnaeus, 1758). Comparative Biochemistry \& Physiology Part A: Molecular \& Integrative Physiology, 242, 110650. https://doi.org/10.1016/j. cbpa.2020.110650

Vazzana, M., Siragusa, T., Arizza, V., Buscaino, G., \& Celi, M. (2015). Cellular responses and HSP70 expression during wound healing in Holothuria tubulosa (Gmelin, 1788). Fish \& Shellfish Immunology, 42, 306315. https://doi.org/10.1016/j.fsi.2014.11.010

Warnau, M., Dutrieux, S., Ledent, G., Rodriguez y Baena, A. M., \& Dúbois, P. (2006). Heavy metals in the sea cucumber Holothuria tubulosa (Echinodermata) from the Mediterranean Posidonia oceanica ecosystem: Body compartment, seasonal, geographical and bathymetric variations. Environmental Bioindicators, 1(4), 268-285. https://doi. org/10.1080/15555270601034388

Xing, K., Yang, H. S., \& Chen, M. Y. (2008). Morphological and ultrastructural characterization of the coelomocytes in Apostichopus japonicus. Aquatic Biology, 2(1), 85-92. https://doi.org/10.3354/ab00038

\section{SUPPORTING INFORMATION}

Additional supporting information may be found in the online version of the article at the publisher's website.

How to cite this article: Queiroz, V., Mauro, M., Arizza, V., Custódio, M. R., \& Vazzana, M. (2021). The use of an integrative approach to identify coelomocytes in three species of the genus Holothuria (Echinodermata). Invertebrate Biology, e12357. https://doi.org/10.1111/ivb.12357 